Studies in African Linguistics

Volume 21, Number 1, April 1990

\title{
FINAL VOWEL SHORTENING IN LUGANDA
}

\author{
Larry M. Hyman \\ University of California, Berkeley
}

\author{
Francis X. Katamba \\ University of Lancaster
}

\begin{abstract}
A process by which long vowels are shortened in "final position" has been noted by a number of linguists, e.g. Ashton et al [1954], Tucker [1962], Cole [1967], Stevick [1969], Katamba [1974], Clements [1986]. It is generally assumed that this shortening is characteristic of word-ends such that the process can even serve as a criterion for phonological word division. Despite the attention given to final vowel shortening (FVS), the relevant facts have not been exhaustively described. In this descriptive account, we show that FVS is a much more complex phenomenon than the Luganda literature suggests. We observe, for instance, that FVS does not work the same on nouns as it does on verbs and that an empirically adequate analysis must take into account the source of such word-final length, e.g. underlying vs. derived. In our solution, FVS first applies at the end of a phonological word (PW) and then again at the end of a clitic group (CG). In order for the facts to fall out from this analysis, we argue that at the PW level (1) the final vowel of verb forms is not affected because it is extrametrical, i.e. "invisible" and (2) the second mora of a monosyllabic stem is not affected because it is accented.
\end{abstract}

\section{Introduction*}

For quite some time, the literature on Luganda phonology has referred to a process by which long vowels are realized short in final position: "...the final syllable of a word spoken in isolation is always short ... Within the sentence too, final syllables of words are usually short, and this fact has been of great value in assessing word division ..." [Tucker 1962:155]. While "final position" is

\footnotetext{
${ }^{*}$ Research on the prosodic structure of Luganda was supported by NSF grant BNS89-96111. We would especially like to thank our principal language consultants, Alice Nabalamba and Frederick Semwogerere, for their help in this project. An earlier and shorter version of this paper was presented at the 20th Annual Conference on African Linguistics, April 22, 1989 at the University of Illinois, Urbana. We would like to thank Russell G. Schuh for his helpful comments made on our submitted manuscript.
} 
generally assumed to mean "at the end of a word", all researchers are aware that such "words", postulated to account for final vowel length, may consist of a "full" word (or "host") and one or more proclitics or enclitics. Thus, speaking of àsòmyê 'he has read', Stevick [1969:4] states: “... the last syllable of the isolated word is short. Before an enclitic, however, it receives the expected two moras ..." Or, to take another example, although the final vowel [a] is phonetically short in (1a), its phonological length is preserved in (1b), where it is followed by the locative enclitic $=k \hat{o}:{ }^{1}$
(1) a. kùlábwà
'to be seen'
b. kùlábwàà=kô
'to be seen a little'
c. kùlábwà wàlúsìmbí
'to be seen by Walusimbi'

In (1c), on the other hand, final length is not preserved on kùlábwà, since the noun object 'Walusimbi' is not an enclitic. Related facts are observed when the host word is preceded by a proclitic, as seen in (2).

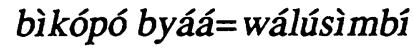

'cups of Walusimbi'

In this case it is the length of the proclitic genitive linker byaa=, rather than the host word, that is preserved in non-final position.

Virtually all researchers comment on the role of such clitics in determining whether underlying word- or clitic-final length will surface. ${ }^{2}$ Lists of environments where phonological vowel length is preserved on or by a clitic are provided in Ashton et al [1954], Tucker [1962], Cole [1967], Stevick [1969], and Hyman, Katamba and Walusimbi [1987]. Although Tucker speaks of a

${ }^{1}$ In these and other examples, an acute accent (á ) marks high $(\mathrm{H})$ tone, a grave accent (à) marks low (L) tone, and a circumflex (â) a HL falling tone. Long vowels are transcribed as double throughout this study. The symbol (=) separates proclitics and enclitics from their host. Hyphens, when present, mark morpheme boundaries, though not all internal morphology is marked in the examples.

2 In standard Luganda orthography, vowel length is written only when it is not predictable from the surrounding segmental environment. Tucker [1962:156] points out that the conventions for marking word division in standard Luganda orthography are only partially successful in capturing whether "final" length will be realized (cf. also Stevick 1969:4). Thus, (1b) is appropriately written as the single word okulabwako (the length of [aa] being predictable from the preceding consonant + glide sequence-see §1.1). Example (2) is written bikopo bya walusimbi. As Tucker observes, the word space after bya should result in the [a] being short. Since it is in fact long, a more adequate practice would be to write a single word byaWalusimbi. There are other cases where standard orthography would have to be modified to account for the complexity of vowel length phenomena described below. In our transcriptions, all surface length is explicitly marked with a double vowel except for the length that automatically occurs before a nasal + consonant sequence. 
"lengthening rule" (p.157), the examples in (3a) show that enclitics do not automatically induce length on their host.

(3) a. kùlábà

kùlábà=kô

kùlábà wàlúsìmbí

b. kù=wàlúsìmbí

nà=wàlúsìmbí 'to see'

'to see a little'

'to see Walusimbi'

'on Walusimbi'

'with Walusimbi'

Similarly, the examples in (3b) show that proclitics do not automatically acquire length from their host. Such observations lead us to conclude that the rule is one of shortening. Following Hyman, Katamba, and Walusimbi, we accept the correctness of a rule of final vowel shortening (FVS) in Luganda.

In this paper we examine the rule of FVS in some detail. In the course of the investigation we will demonstrate that FVS takes place both at the end of a phonological word (PW) and at the end of a clitic group (CG). We will begin in $\$ 1$ by identifying the structures which constitute CG's for the purpose of FVS. With these CG's firmly established, we then consider the exact operation of the FVS rule, first within nominal CG's (NCG's) in §2, and then within verbal CG's (VCG's) in §3. As we shall see, FVS applies differently within a NCG vs. a VCG according to the source of the final vowel length, e.g. underlying vs. derived. The generalization is that FVS must apply at the end of a nominal PW but not at the end of a verbal PW. An analysis involving "invisibility" (extraprosodicity) is presented in $\S 4$ that accounts for this difference. In $\$ 5$ we extend the account of FVS to adjectives and test our claims against two other constructions (compounds and reduplications), which are shown to support the analysis. In $\S 6$ we conclude with some cases of apparent under- and overapplication of FVS, including possible word-internal applications.

\section{The Clitic Group}

In this section we shall enumerate what we believe to be an exhaustive list of phonological proclitics and enclitics in Luganda. As will be seen, whether a given "particle" will function as a phonological clitic (as defined by FVS and tonal criteria) or as a separate full word is not always predictable from its phonological shape or grammatical properties. We shall first consider proclitics, then enclitics, distinguishing in each case between those whose host is nominal vs. those whose host is verbal. We then consider the same distinction among enclitics. 
1.1. Proclitics. The class of proclitics in Luganda consists of a limited number of particle-like elements that fall into a few well-defined classes. In (4) we list those proclitics whose host is "nominal". 3
(4) a. $b a=$
'class 2a'
$z i=\quad$ 'class $10 \mathrm{a}$ '
b. $k u=$ 'class 17 '
$m u=$ 'class 18 '
c. na/ne
'with/and/even'
d. -aa
'genitive linker' (GL)

All proclitics have in common that they are toneless. ${ }^{4}$ Those in (4a) are plural class markers used with a restricted set of nominals, e.g. proper names (bà=wàlúsìmbí 'the Walusimbis'), borrowings (zì=lòolê 'lorries') and other forms. ${ }^{5}$ Those in (4b) are locative markers, e.g. mù=nnyúmbà 'in the house', kù=kìtábó 'on the book' etc., 6 while na/ne in (4c) is the versatile preposition having the indicated translations, e.g. nà=wàlúsìmbí 'with/and/even Walusimbi'.7 Since none of the proclitics in (4a-c) have an underlying long vowel to be preserved within the CG, it is tone and not the FVS rule that tells us that these are proclitics rather than prefixes or independent words.

This brings us to the genitive linker (GL) in (4d), as seen in examples such as (5):

${ }^{3}$ By this is meant that the following host will either be an actual noun, e.g. mù=bikópò 'in the cups', or will be a noun modifier functioning as head, e.g. mù=binò 'in these'.

${ }^{4}$ This statement must be qualified somewhat, given the unique status of the so-called initial vowel or augment, e.g. è-bitábó 'books'. This morpheme has an underlying $\mathrm{H}$ tone which, however, is deleted at the beginning of a CG [Hyman and Katamba 1990]. Based on tonal criteria, a CG-initial (toneless) augment has the properties of a word-level prefix; when internal to a CG and therefore H-toned, it seems to be a proclitic. For reasons of simplicity, we have attempted to provide forms without the augment whenever possible.

5There may be a few class 8 bi= and class 14 bu= proclitics as well, e.g. bù=kàmúnye 'hawks' (see Cole 1967:27).

6 Of the very few forms with frozen locative class 16 wa-, the form wà=ǹs $\hat{i}$ 'on the ground' conceivably consists of a proclitic + host (since ǹsî by itself means 'earth, country'). In other cases, wa- clearly is a prefix, e.g. wàlálá 'elsewhere', wàntú 'someplace'. Class 16 wa- should not be confused with the class la wa- prefix of personification, e.g. wánjóvú 'Mr. Elephant' (cf. ǹjóvú 'elephant'). While this marker has some tonal peculiarities of its own, it must be analyzed as a prefix, not a proclitic.

7 As shown in Hyman and Katamba [1990], the ne variant is used in contexts where the grammar requires an augment on the following host. As mentioned in note 4 , the augment has an underlying (sometimes floating) $\mathrm{H}$ tone which it contributes to the proclitic, as in ne=mùlóndó 'with Mulondo'. 

(5) a. ki kópó kyáá=wálúsìmbí
'cup of Walusimbi'
b. lùggí lwáá=wálúsìmbí
'door of Walusimbi'
c. bááná báá=wálúsìmbí
'children of Walusimbi'

Here, the GL takes a noun class agreement prefix, respectively, class $7 \mathrm{ki}-$, class $11 \mathrm{lu}$ - and class $2 \mathrm{ba}$-. In Luganda, as summarized in (6), high vowels glide and non-high vowels delete before another vowel which, if short, exhibits compensatory lengthening (see Tucker [1962]; Halle and Vergnaud [1980]; Katamba [1974]; Clements [1986], among others).
(6) a. $/ \mathrm{Ci}+\mathrm{a} /, / \mathrm{Cu}+\mathrm{a} /$
$\rightarrow \quad[$ Cyaa $],[$ Cwaa $]$
b. $/ \mathrm{Ce}+\mathrm{a} /, / \mathrm{Co}+\mathrm{a} /, / \mathrm{Ca}+\mathrm{a} /$
$\rightarrow \quad[\mathrm{Caa}]$

It is not possible to tell from (5) if the GL itself should be analyzed with underlying /a/ or $/ a a /$. Since a syllable cannot exceed two moras, one would obtain the same surface realization [kyaa] from $/ k i+a /$ or $/ k i+a a /$, [lwaa] from $/ l u+a /$ or $/ l u+a a /$, and (baa) from $/ b a+a /$ or $/ b a+a a /$. Onsetless sequences of $/ i+a /$ and $/ u+a /$ undergo gliding without compensatory lengthening and are realized [ya] and [wa]. Thus, the proclitics in (7) must be analyzed as /i+aa/ and /u+aa/ in order to obtain the correct surface length: ${ }^{8}$
(7) a. mìbwá yáá=wálúsìmbí
'dog [cl. 9] of Walusimbi'
b. mwááná wáá=wálúsìmbí
'child [cl. 1] of Walusimbi'

We conclude that the GL is underlyingly $/-a a /$, not $/-a / .9$ The preservation of two vowel lengths in (6) and (7) is thus attributable to the fact that the GL is a proclitic, not a self-standing word.

8It should be noted that compensatory lengthening of $/ \mathrm{Cia} /$ and $/ \mathrm{Cua} /$ to [Cyaa] and [Cwaa] is possible only when there is an onset consonant. While this fact sometimes goes unmentioned in previous literature, Clements [1986:75] has suggested that forms such as [yàlábà] 'he saw' and [wàlábà] 'you (sg.) saw' (from /i+a/ and /u+a/, respectively) are derived by a special lexical rule. As we will see in the case of verbal proclitics, the onset requirement for compensatory lengthening is quite robust in Luganda, and hence, these forms are not exceptional.

${ }^{9}$ This conclusion has interesting consequences for possessive pronouns. Forms such as byange 'my', byaffe 'our', byammwe 'your pl.' and byaabwe 'their' show an internal GL and hence have the morphological divisions bi-aa-nge, bi-aa-ffe, bi-aa-mmwe, and bi-aa-bwe (sidestepping the question of whether the final [e] is also a morpheme). The remaining two possessive pronouns, byo 'your sg.' and bye 'his/her', have the internal structure bi-aa-o and bi-aa-e, i.e. with four underlying vowel lengths. The rules in (5) will require gliding of /i/ and deletion of /aa/, both with compensatory lengthening. The restriction of at most two moras to the syllable will require that hypothetical *byoooo and *byeeee be converted to byoo and byee, which may then undergo FVS to become byo and bye in the appropriate context. This two-step analysis whereby 
As seen in (8), it is possible to get more than one GL in sequence with length preserved on each one:

(8) a. bìkópó byáá=wáá=wálúsìmbí

b. bìkópó byáá=wáá=múlúlû bìkópò byàà=wàà=kìsá

'the cups of the one of Walusimbi'

'the cups of the greedy one'

'the cups of the kind one'

In (8) we have a double genitive construction with the second genitive lacking an overt head. In (8a) the second GL expresses possession, while in (8b) it expresses an attribute (literally, 'the cups of the one of greediness', 'the cups of the one of kindness'). Longer sequences of GL's, each with retained vowel length, are logically possible but pragmatically awkward.

We turn now to proclitics whose host is verbal.10 The first concerns the subject cleft marker /-ee/, illustrated in (9).
(9) a. kìkópò kyèè=kyáágwà
'it's a cup that fell'
lùggi lwèè=lwáágwà
'it's a door that fell'
báánà bèè=báágwà
'it's children that fell'
b. m̀̀bwâ yèè=yàgwâ
'it's a dog that fell'
mwáánà yèè=yàgwâ
'it's a child that fell'

We see in (9a) that the marker/-ee/ agrees in noun class with the clefted noun phrase. Preservation of length in [kyee], [lwee], and [bee] shows that this marker is procliticized onto the verb. The forms in (9b) show, first, that both classes 1 and 9 assign an / $i-/$ agreement to the subject cleft marker and, second, that this marker must be underlyingly long (cf. the discussion of the GL above).

A slightly different situation is observed when the host of this proclitic is nominal:
a. kìnò kyèè=kìkópò
lùnò lwè̀̀=lùggí
bànò bè̀=báàná

\begin{abstract}
'this is the cup'
'this is the door'

'these are the children'
\end{abstract}

multiple vowel sequences are first pared to a maximally bimoraic syllable and then to a monomoraic syllable (in "final" position) seems preferable to an analysis whereby FVS may apply directly to *byoooo and *byeeee to delete all but one mora.

10 The host will normally be a verb, though in the case of the zero copula, there is no overt verb on the surface. 

b. ènò yè=lòòlê
ònò yè=mwáàná
'this is the lorry' [cl. 9] 11
'this is the child'

The examples in (10a) parallel those in (9a), with appropriate surface vowel length on the proclitic. The examples in (10b), however, show a short vowel on $y \grave{e}=$ (which, recall, can mark either class 1 or class 9). In the examples in (10), then, the cleft marker must be set up as /-e/, i.e. with an underlying short vowel. While we have no explanation for this, the descriptively correct statement is that the subject cleft marker will be /-ee/ unless it is directly followed by a zero copula, used in the present, as in (10). When we change (10) to past tense, for instance, where an overt copula is required, the proclitic again has the underlying representation /-ee/, e.g. ènò yè̀̀=yàlí lóólê 'this was the lorry'. In this example, yèè= is proclitic to yàlî '(it) was', which is a verb form parallel to yàgwâ '(it) fell' in (9b). 12

It is appropriate to compare the marking of non-subject clefts, illustrated in (11).
(11) a. kikópò kyè yàlábà
'it's a cup that he saw'
lùggì lwè yàlábà
'it's a door that he saw'
báánà bè yàlábà
'it's children that he saw'
b. ṁ̀bwâ gyè yàlábà
mwáánà gwè yàlábà
'it's a dog that he saw'
'it's a child that he saw'

In these examples the clefted NP is object of the sentence. As seen in (11a), we do not get surface vowel length, even though the underlying representations include at least two vowel lengths, i.e. / $/ \mathrm{ki}-\mathrm{e} / \mathrm{l} / \mathrm{lu}-\mathrm{e} / \mathrm{/} / \mathrm{ba}-\mathrm{e} /$. While the subject cleft marker in (10b) was [yè] for both class 9 and class 1 , we see in (11b) that the non-subject cleft marker is [gyè] for class 9 and [gwè] for class 1 . The uniform shortness of the vowel [e] throughout (11) indicates that the marker is not a proclitic, but rather a separate word. 13 This and the segmental differences

\footnotetext{
${ }^{11}$ In this example we have replaced mìbwâ 'dog' from (9b) with lò̀lê 'lorry, truck', since in the corresponding utterance, ènò yè=mbwâ 'this is the dog', the vowel on yè is phonetically long because of the following NC sequence (see Tucker [1962]; Herbert [1975]; Clements [1986], etc.).

12 An alternative solution would be that /-ee/ is a proclitic unless (a) it is followed by a zero copula and (b) its noun class agreement is $/ i-l$, i.e. a vowel without a preceding onset consonant, in which case it is a separate word (and undergoes FVS). We do not find anything to commend this analysis.

${ }^{13}$ This conclusion is supported by the fact that it functions as a separate PW within the tone group domain.
} 
observed in (10b) vs. (11b) may suggest that these are entirely different markers, despite the obvious phonetic and grammatical similarities. Whatever the decision on this point, it is important to note two things about Luganda. First, one cannot predict the proclitic vs. word status of a "particle" on the basis of its phonetic shape, e.g. whether it is monosyllabic, for instance. Second, one cannot predict that a syntactically proclitic element will necessarily be a phonological proclitic. The data in (12) show this second point quite clearly:
a. kìkópò wàlúsìmbì kyè yàlábà
'it's a cup that Walusimbi saw'
b. ṁ̀bwâ wàlúsìmbì gyè yàlábà
'it's a dog that Walusimbi saw'

In non-subject clefts, the subject of the lower clause appears before the cleft marker. As pointed out by Walusimbi [1976], the same observation pertains to non-subject relative clauses, which differ from their cleft counterpart in tonal ways only. In both constructions the complementizer must immediately precede the verb, suggesting that it is syntactically dependent ("leaning") on it. Yet, as we have seen, the phonology treats these markers as separate words. We arrive at the same conclusion reached by Klavans [1985], who observed that syntactic and phonological cliticization are logically independent of each other. This independence is also exemplified by Luganda enclitics, a topic to which we now turn. 14

1.2. Enclitics. The complete set of nominal enclitics, given in (13), consists of one WH enclitic and the six personal possessive pronouns:
a. =ki 'which'
b. -ange 'my'
-affe 'our'
$-0$
'your sg.'
-ammwe
'your pl.'
$-e$
'his/her'
-aabwe
'their'15

Preservation of final noun length before these enclitics is illustrated with the class 9 noun mibwâ 'dog' in (14):

${ }^{14}$ Although we were able to illustrate multiple nominal proclitics in (7), we cannot provide uninterrupted sequences of verbal proclitics due to their syntactic nature. It should be pointed out that there are fewer verbal proclitics in the language than there are nominal proclitics. In some cases, e.g. the main clause negative markers te-/si- and the narrative tense marker ne-, it is not possible to tell whether these are proclitics or merely prefixes that must occur initially within the verb.

15Possessive forms all contain the GL /aa/, as we noted above. In these forms it should be noted that length resulting from a following NC sequence, e.g. [-aange], is not transcribed; also, a vowel is automatically short before a geminate consonant, e.g. [-affe, -ammwe]. 
(14) a. mìbwáà=kí

b. mìbwáá=yàngé

ṁ̀bwáá=yò

m̀̀bwáá $=y e ̀$

mìbwáá=yàffé

ṁ̀bwáá=yàmmwé

mìbwáá=yààbwé

c. ṁ̀bwá yáá=wálúsìmbí 'which dog?'16

'my dog'

'your sg. dog'

'his/her dog'

'our dog'

'your pl. dog'

'their dog'

'dog of Walusimbi'

The final length of 'dog' is realized before the enclitic $=k i$ 'which' in (14a) and the six personal pronouns in (14b). In (14c) we demonstrate that final length is not preserved when mibwâ fails to be followed by an enclitic. As discussed in $\S 1.1$, yaa $=$ walusimbi consists of a proclitic GL + host noun. Since this combination is not an enclitic, FVS applies, and the final vowel of 'dog' is short.

There are no other enclitics on nouns in Luganda. Likely candidates are dismissed by the data in (15), where the length of the head noun 'dog' is not preserved:
(15) a. mìbwá yáábyô
'their [class 8] dog'
b. ṁ̀bwâ yô
'as for the dog'
c. ṁ̀bwá ènó
'this dog'
d. ṁ̀bwá èmû
'one dog'

While the six personal possessive pronouns in (13b) are enclitics, we observe in (15a) that NON-personal possessives consisting of a GL + independent pronoun, here class 8 byô, are not. Although all clitics other than the six personal possessives are monosyllabic in Luganda, the monosyllabic topic marker $-o$ in (15b) is not an enclitic. Finally, (15c) and (15d) are intended to show that demonstratives and numerals are also not enclitics.

Although nominal enclitics are limited to those in (13), the example in (16a) shows that it is possible to get two nominal enclitics in sequence:
a. kìkópó=kyéè=kí
'which cup of his/hers?'
b. ṁ̀bwáá=yàngè=kí
'which dog of mine?'

${ }^{16}$ The enclitic =kí requires that the nominal mìbwâ 'dog' occur with a surface HL contour, since a noun does not form a tone group with this enclitic (see Hyman, Walusimbi and Katamba [1987]). 
In this case it is the length on the possessive pronoun kyée 'his/her' that is preserved by the enclitic $=k i$. In (16b) we see preservation of final length on the noun 'dog', as before. Because of the way FVS affects nouns and their possessive enclitics (cf. (37)), the language does not provide any example with final length preserved on both the noun and the possessive pronoun. Taken together, however, (16a) and (16b) establish that each example consists of a single CG with two enclitics in sequence.

Turning now to verbal enclitics, these fall into two categories consisting, respectively, of the two WH enclitics in (17a) and the four "locative" enclitics in (17b).
(17) a. =kí
'what'
=wá
'where'
b. $=$ wô
'there (particular place)
(class 16)
$=k \hat{o}$
'on, upon'
(class 17)
$=m \hat{u}$
'in, inside, within'
(class 18)
$=y \hat{o}$
'there (away from speaker)
(class 23)

The two WH enclitics in (17a) are illustrated in (18). 17
a. yàsímá=kí
'what did he dig?'
b. yàsímá=wá
'where did he dig?'

As indicated, the locative enclitics in (17b) function as part of the noun class system and are identified as classes $16,17,18$, and 23.18 Examples are given in (19).

${ }^{17}$ One might consider adding other WH particles to the list of enclitics such as =àní ' who(m)' and $=d d i ́$ ' $w$ hen'. Like =kí and =wá, =àní and =ddí must come immediately after the verb in what we would claim is a focus position. However, with these latter enclitics it is impossible to use vowel length preservation as a criterion for enclitic status: with =àní, vowel length will always surface, since =àní begins with a vowel (and will always join the preceding vowel to form a bimoraic syllable); with $=d d i$, the geminate consonant requires that any preceding vowel be short, independent of the number of underlying moras (see Tucker [1962]; Katamba [1974]; Clements [1986]).

${ }^{18}$ These enclitics suggest a pronominal element $-o$. Classes 16 and 20 are then analyzed as /wa-o/ and $/ \mathrm{i}-\mathrm{o} /$ and are phonologically regular. Class $17 / \mathrm{ku}-\mathrm{o} /$ is exceptional, since this underlying representation would be realized incorrectly as $*[k w o]$, not $[k o]$. Class $18[\mathrm{mu}]$ is exceptional in not taking $-\mathrm{O}$ at all. Underlying / wa-, $\mathrm{ku}-, \mathrm{mu}-, \mathrm{i}-\mathrm{/}$ is motivated by the rest of the noun class system (see Ashton et al [1954]; Cole [1967]). 

(19) a. yàtúúlá=wô
'he sat there'
b. yàtúúlá=kô
'he sat thereon'
c. yàtúúlá=mû
'he sat therein'
d. yàtúúlá=yô
'he sat yonder'

In addition to their locative meanings, the class 17 and 18 enclitics also have a partitive or attenuative function, as illustrated in (20).

(20)
a. yàlyáá=kô
'he ate a little'
b. yàlyáá=kô èbîì
'he ate two of them [class 4]'
c. yànywáá=mû
'he drank a little'

Finally, (21) shows that any of the four locative enclitics may be lexicalized in combination with specific verbs, as in the following examples taken from Snoxall [1967]:

(21)
a. òkûddá
'to come back'
òkúddà=wô
'to go back'
òkúddà=kô
'to be born, come next in order'
òkúddà=mû
'to answer'
òkúddà= $y \hat{o}$
'to go back there, return'
b. òkúggyá
òkwéggyá=wô
'to take' (cf. òkwêggyá 'to take oneself')
òkwéggyá $=m \hat{u}$
'to start' (take oneself away)
'to think of' (take within oneself)

The forms in (17) can be shown to be enclitics by the criterion of vowel length preservation, as will be further examined in $\S 3$. To conclude this section, consider the examples in (22).

(22) a. yátéésé kú=múpûngà mù=ki byá

'he put some rice in the bowl'

b. yákítééséé=mû kù=mùpûngá

'he put some rice in it'

c. yákitééséé=múu $=k \hat{o}$

'he put a little in it'

d. yákitééséé=múù=kóò=kí

'what did he put a little of in?'

In (22a) we have a verb form followed by two full words, each beginning with a locative proclitic. As seen in (22b), the verb has underlying final length 
preserved by the locative enclitic $=$ mû. ${ }^{19}$ We thus conclude that FVS has applied in (22a), where the verb is not followed by an enclitic. (22c) shows that when there are two enclitics in sequence, final length is preserved both on the verb and on the first enclitic. Finally, in (22d), where there are three enclitics in sequence, again final length is preserved on each element within the CG except the last.

As in the case of proclitics and nominal enclitics, one cannot predict which syntactic enclitics are also phonological enclitics. In (23a) final length is preserved on a verb before the phonological enclitics $=k \hat{o}$ and $=k \hat{i}$ :
a. yàlyáá=kô
'he ate a little'
yàlábwáá=kí
'what was he seen by?'
b. yàlyá kyô
'he ate IT [class 7]'
yàlábwá yê
'he was seen by HIM'

Example (23b), on the other hand, shows that emphatic pronouns are not phonological enclitics, since FVS has applied to the preceding verbs. This is striking for two reasons. First, emphatic pronouns, when postverbal, must immediately follow the verb, suggesting that they are syntactically "leaning" on the verb. 20 Phonologically, however, they do not lean on the verb, but rather are full words in their own right. Second, emphatic pronouns share with all verbal enclitics the property of being monosyllabic. Any form that is plurisyllabic will automatically not be a verbal enclitic, as seen from the comparison of the WH-forms in (24).21
(24) a. yàlyáá=kí
b. yàlyá kíkí
c. yàlyá bíkí
'what did he eat?'
'what (class 7 sg.) did he eat?'
'what (class 8 pl.) did he eat?'

Example (24a) utilizes the WH-enclitic $=k i$, which is unmarked for number. On the other hand, the WH-words are marked by a singular class 7 prefix $\mathrm{ki}$ - in

${ }^{19}$ The verb stem consists of the root -teek- 'put' followed by the "modified base" ending -ie [Ashton et al 1954]. In this case, there is consonant mutation (-teesie-) followed by gliding with compensatory lengthening (-teesyee-), y-aborption after [ $s]$ (-teesee-) and, in (22a), FVS. Note also that the class 17 proclitic $k u=$ in $(22 a, b)$ has the same partitive meaning as its enclitic counterpart $=k \hat{o}$ in (20a).

${ }^{20}$ WH-enclitics also must immediately follow the verb. As a result, they may not cooccur with emphatic pronouns. Finally, Luganda does not permit more than one WH-enclitic or emphatic pronoun in sequence.

${ }^{21}$ Given the requirement of monosyllabicity, it seems unlikely that àní 'who(m)' would be an enclitic (cf. note 17). The plural form bààní clearly is not an enclitic, e.g. yàlábwá bááni 'who (pl.) was he seen by?'. 
(24b) and the corresponding plural class 8 prefix bi- in (24c). Because of their bisyllabicity, kikí and bìkí cannot be verbal enclitics. Instead, they are full words, and FVS applies to the verb. This contrasts with bisyllabic personal possessives, which, as we saw in (14b), are nominal enclitics, not full words. As we shall now see, there are other differences between nominal vs. verbal CG's.

\section{FVS in the Nominal Clitic Group (NCG)}

In the preceding section we distinguished between nominal and verbal CG's and established that each admits a limited set of proclitic and enclitic elements. It has been assumed up to this point that there is a rule of FVS that applies at the end of a CG, as stated informally as follows:

$$
\mathrm{VV} \rightarrow \mathrm{V} /[]_{\mathrm{CG}}
$$

In this section we shall see that while the above rule is a correct statement, as far as it goes, it does not by itself account for all of the complexities of FVS. As we shall now see, FVS sometimes applies within the CG. In order to give a complete account of FVS, it will be necessary, first, to consider NCG's separately from VCG's, as we do in this and the next section. Second, we must recognize that the application of FVS is affected by the specific source of the final vowel length. In particular, the following three sources of final vowel length must be distinguished: (a) monosyllabic vowel length; (b) contour tone vowel length; (c) underlying vowel length. We shall now consider each of these in turn.

2.1. Monosyllabic vowel length. As stated by Stevick [1969:5], “...so-called monosyllabic stems all have two moras". Similar observations had been made by Ashton et al [1954:401,423], Tucker [1962:157], and Cole [1967:61]. The motivation for requiring two moras for all monosyllabic stems comes from noun forms such as in (25).
(25) a. ǹté
'cow'
ǹtéé=kî
'which cow?'
màtá
'milk'
màtáá=kí
'which milk?'
kìdé 'bell'
kìdéé=kí
'which bell?'
b. ǹ̀téé=yàngé, ǹtéé=yò
'my cow, your sg. cow', etc.
màtáá=gàngé, màtáá=gò
'my milk, your sg. milk', etc.
kìdéé=kyàngé, kìdéé=kyò
'my bell, your sg. bell', etc. 
The nouns in (25) consist of a noun class prefix and a monosyllabic stem, i.e. ǹ-té, mà-tá, kì-dé. In (25a) we see that the stem vowel is long before the WH enclitic $=k i$, while in (25b) we see that the stem vowel is long before a personal possessive enclitic (here, 'my' and 'your sg.'). The interpretation of these facts is the following: all stems in Luganda must have at least two moras, perhaps the effect of an accent on the second stem mora (see Hyman [1989]). Either monosyllabic stems are represented underlyingly with two moras, i.e. /-tee, -taa, -dee/, or there is a rule introducing the second mora. In either case, this "monosyllabic length" is preserved when the stem is followed by an enclitic, since this length is not CG-final.

2.2. Contour tone vowel length. The second source of final vowel length comes from the realization of contour tones [Ashton et al 1954:424,452; Tucker 1962:157; Cole 1967:67-68,88; Stevick 1969:6; Hyman 1982:13]. Ignoring an utterance-level downstepping phenomenon, Luganda has two surface tones, $\mathrm{H}$ (igh) and L(ow), which, conditions being met, can combine to form a HL falling contour tone. (Luganda does not allow LH rising tones.) Within a word this HL contour will always be realized on two separate moras. The two moras may either be two vowels, as in (26a), or one vowel + the first half of a geminate consonant, as in (26b).

a. mwáàná

kìjî̀kó

b. máżzí

kíssí 'child'

'spoon'

'water'

'bait'

At the end of a word, the situation is considerably more complex. As seen in (27a), a final HL falling tone may be realized on a short vowel:
a. mùsòtâ
'snake'
kìsìkî
'log'
b. mùsòtáà=kí
'which snake?'
kìsìkî̀=kí
'which log?' 
As soon as the $\mathrm{HL}$ is found within a CG, however, the expected two moras surface, as seen in (27b).22 In this case we do not want to say that this vowel length is underlying, since the second mora is predictable from the tone rules of Luganda. Following Hyman [1982], we propose to introduce this vowel length by rule. The only underlying tone in Luganda is $\mathrm{H}$, and words may have one, more than one or no underlying $\mathrm{H}$ tone at all. Nouns such as in (27a) begin with a single underlying $\mathrm{H}$ tone on their final mora, as seen in the inputs in (28).
(28)
a. musota
$\rightarrow$
musota
HL
$\rightarrow$
musotaa
$\mathrm{H}$
$\mathrm{HL}$
b. kisiki
kisiki
HL
$\rightarrow \quad$ kisikii
$\mathrm{H}$

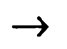
$\mathrm{HL}$

The drop to $L$ is accomplished by a general rule of $L$ tone insertion (see Hyman, Katamba and Walusimbi [1987]). Since in these forms there is no tone-bearing unit for the $\mathrm{L}$ to link to, a mora is inserted to accommodate it. The output forms in (28) thus serve as potential inputs to the FVS rule, hence the final short vowels observed in (27a). In (27b), however, the vowel length in the HL syllables is not affected by FVS, since these nouns are immediately followed by an enclitic.

A similar situation is observed when the same two nouns are followed by a possessive pronoun:

(29)
a. mùsòtáá=gwàngé
'my snake'
kìsì kîi= kyàngé
'my log'
b. òmùsótà=gwàngé
'my snake'
èkìsîkì=kyàngé
'my log'

As seen in (29a), the final vowel of these nouns is long before the possessive 'my'. Although the word-final HL is not actually realized in these examples, there can be no doubt that it is responsible for the length in (29a).23 Now note the forms in (29b). When the augment (initial vowel) is present, the nouns òmùsótà 'snake' and èkìsíkì 'log' have a H-L pattern realized over their last two syllables. Since their tonal derivation does not involve a HL fall on their last syllable, there is no mora-insertion and, hence, they end short before an enclitic.

${ }^{22}$ As pointed out in (3) above, an enclitic never introduces new length on a preceding vowel. Thus, mùkázì 'woman' is realized with a final short vowel in the CG mùkázì $k k^{\prime}$ 'which woman?'.

${ }^{23}$ The reason why the $\mathrm{HL}$ is not preserved has to do with the realization of tone within a tone group (see Hyman, Katamba and Walusimbi [1987] and §4.2). 
Other tone patterns that end in a falling tone also show the length when internal to a CG:

a. mùsíkâ

mùsíkáà=kí

mùsíkáá=wàngé

b. mùvúbúkâ

mùvúbúkáà=kí

mùvúbúkáá=wàngé 'heir'

'which heir?'

'my heir'

'young adolescent'

'which adolescent?'

'my adolescent'

Since contour tone length is derived, the correct ordering statement will have to be with mora-insertion applying before FVS. In other words, forms such as mùsòtâ 'snake' start out with a final short vowel with underlying $\mathrm{H}$, undergo $\mathrm{L}$ tone insertion, acquire length to accommodate the floating inserted $\mathrm{L}$, and then lose this length by FVS whenever in CG-final position. 24

2.3. Underlying vowel length. We now turn to nouns that end in a sequence of underlying vowels. We can infer an underlying vowel sequence most readily from the presence of a surface consonant + glide + vowel sequence, where the glide comes from an underlying high vowel. Examples are given in (31).

${ }^{24}$ There is actually possible variation. Monosyllabic length is always preserved when followed by an enclitic. So is contour tone length always preserved if the contour actual surfaces. In both cases the length is both obligatory and markedly greater in duration than a corresponding short vowel. If the contour does not surface, some speakers require that the vowel be long, while others accept either a long or short vowel, e.g. either kìsìkíi=kyàngé or kì sìkí=kyàngé 'my log'. More perplexing than this are the following putative minimal pairs cited, respectively, by Cole [1967:7] and Tucker [1962:163]:

$\begin{array}{lll}\begin{array}{l}\text { mùwàláá=wàngé } \\ \text { mùwàlá=wàngé }\end{array} & \begin{array}{l}\text { 'my girlfriend' } \\ \text { mùgòléé=wàffé }\end{array} & \text { (mù daughter' } \\ \text { mùgòlé }=\text { 'où 'girfé } & \text { 'our bride' } & \text { (mùgòlê 'bride, mistress of house') }\end{array}$

These data are puzzling for a number of reasons. First, there is no obvious basis for such a length distinction, since the same noun with the same underlying tone is involved in both forms in each pair. (The glosses of the nouns in isolation given to the right are taken from Snoxall [1967].) Second, both the second author and our principal language consultant (Mr. Semwogerere) accept only a short vowel in these phrases, whatever the meaning. Third, we have not been able to find anyone who accepts these distinctions. We cannot explain why only these two $\mathrm{H}$-final nouns should be realized with a short vowel before a possessive pronoun. (Before the enclitic $=k$ i a $\mathrm{HL}$ fall is realized over two moras, e.g. mùwàláà=kí 'which girl?, which daughter?'.) A possible solution would be to set up underlying toneless allomorphs of these two nouns used only with a possessive pronoun, which would assign a $\mathrm{H}$ to the preceding (short) vowel. 
(31) a. kíkòlwá

mùgwáágwá

kìnyéèbwá

b. kìwábyò

mìmámbyà

ǹgóbyá 'deed'

'fool'

'groundnut'

'sickle'

'dawn'

'deceit'

The nouns in (31a) end in $/ \mathrm{CuV} /$, while those in (31b) end in $/ \mathrm{CiV} /$. As was seen above in (6a), the expectation is that the high vowel will glide to [w] and $[y]$ with compensatory lengthening of the following vowel, e.g. /kikolua/ $\rightarrow$ kikolwaa, etc. The long vowel then is subject to FVS at the end of a CG, as in the isolated forms in (31).

The forms in (32), however, show these nouns with a final short vowel even though they appear internal to a CG:
a. kíkòlwà=kí
'which deed?'
mùgwáágwá=kí
'which fool?'
kìnyéébwà=kí
'which groundnut?'
b. kìwábyò=kí
'which sickle?'
ǹmmámbyà=kí
'which dawn?'
ǹgóbyá=kí
'which deceit?'

Final short vowels are also observed when the same nouns are followed by a possessive enclitic, as seen in (33).
a. kíkólwá=kyàngé
'my deed'
mùgwáágwà=wàngé
'my fool'
kìnyéébwá=kyàngé
'my groundnut'
b. kì wábyò=kyàngé
'my sickle'
ǹmámbyà=yàngé
'my dawn'
ǹgòbyá=wàngé
'my deceit'

This is a surprising result: the whole literature on Luganda has assumed a bimoraic source of CGV sequences, and yet, other than the surface glide, (non- 
derived) nouns provide no phonological evidence of there ever having been a final vowel sequence, i.e. two moras. CG-internally, other nouns stems may have final CGVV length not because of the glide, but because of their monosyllabicity (34a), their HL contour tone (34b), or both (34c):

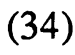
a. kìkwáá=kí
kìbyáá=kí
b. kìbògwéè=kí
kìuúlúkwáà=kí
c. mùtwéè=kí
kàmyúùu=kí

'which bad luck?'

'which bowl?'

'which partly ripened fruit?' (kì-bògwê)

'which deserted place?'

'which head?'

'which hare?' (kì-kwâ)

(kì-byâ)

(kì-fúlúkwâ)

(mù-twê)

(kà-myû)

There are two possible interpretations of the facts in (32) and (33). The first is that a final $\mathrm{CwV}$ or $\mathrm{CyV}$ syllable is underlyingly monomoraic in nouns (but not in verbs, as we shall see in §3). The second interpretation is that noun-final $\mathrm{CwV}$ and CyV syllables are underlyingly bimoraic but undergo FVS (unless the noun stem is monosyllabic and/or acquires a HL contour). We will now argue that the second interpretation is correct.

According to the first interpretation, nouns such as kíkòlwá and kì wábyò end in an underlyingly monomoraic syllable. One way to effect this is to assume that the glides are underlying - alternatively that they "float" without a V or moraic support. In either case the analysis runs counter to the general syllable structure of the language: the first suggestion sets up underlying CG sequences that do not otherwise exist; the second sets up totally predictable non-moraic vowels that otherwise do not exist. ${ }^{25}$ A second argument against the monomoraic analysis is first suggested by the noun kíkòlwá 'deed'. This noun derives from the relative verb form èkikòlwà 'that which is done', consisting of the morphemes e-ki-kol-u-a (augment-subject prefix-verb-passive suffix-final vowel). Since there are clearly two moraic morphemes in this form, the passive - $u$ - and the final vowel $-\mathbf{a}$, the motivation for a bimoraic source in the corresponding noun form is clear.

Still, one could argue that kíkòlwà 'deed' is simply listed as a noun (with a final monomoraic syllable) not derived from the corresponding verb form. Fortunately there are productive means of forming deverbal nouns to which we

$25 \mathrm{It}$ is appropriate to mention certain [ggwa] and [ggya] sequences which also do not show vowel length internal to a CG: g̀gwaníká 'store', kùggyá=mû 'to take out of', etc. In this case the underlying representation is not /gua/ and /gial. Instead, these sequences derive from intermediate ${ }^{*} w w a$ and $*_{y y a}$, which obligatorily undergo hardening, since geminate glides are disallowed in Luganda (cf. \$6.2). 
can add nominal enclitics to test for underlying final bimoricity. The first of these is the very relative construction that is responsible for kíkòlwá, exemplified in (35).
a. à-bá-á-làb-w-á
b. à-bá-á-láb-w-áá=kí
c. bá-á-làb-w-à=kí

'the ones that were seen'

'the ones that were seen by what?'

'which ones that were seen?'

In (35a), the verb stem is /lab-u-a/, consisting of the root -lab- 'see', the passive suffix - $u$-, and the final vowel -a (henceforth FV). In (35b) we see that when the verbal $\mathrm{WH}$ enclitic $=k i$ ' ' $w$ hat' is placed after this relative form, indicating the agent of the passive, the final compensatory lengthening acquired through gliding to $[w]$ is preserved. On the other hand, in (35c), where we place the nominal WH enclitic $=k i$ ' $w h i c h$ ' after the same form (though obligatorily without its initial augment vowel à-), we see that the length is not preserved. Since the same morphemes are involved, and since the productively created form in (35c) should not be listed as an independent noun in the lexicon, we must conclude that the final syllable of such deverbal nouns is bimoraic, but subject to some version of FVS. 26

The same is seen in infinitives, the second source of productive deverbal nominals:
a. kùlábwà
'to be seen'
$|l a b-u-a|$
b. kùlábwàà=kô
'to be seen a little'
kùlábwàà=kí
'to be seen by what?'
c. kùlábwà=kwàngé
'my being seen'
kùlábwà=kí
'which being seen?'

(36a) gives the basic infinitive form with the same passive stem as seen in (35). In (36b) the verbal enclitics $=k \hat{o}$ and $=k i$ preserve the final length of the

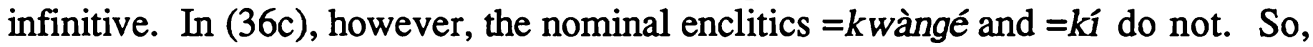
again, we have evidence that nominals must undergo a special FVS rule that verbs

\footnotetext{
${ }^{26}$ The same vowel length discrepancy between verbal vs. nominal uses of relative forms is seen with other enclitics. Thus, final length is preserved by the verbal enclitic $=k \hat{o}$ in àbáálábwáá $=k \hat{o}$ 'the ones who were seen a little'. On the other hand, final length is not preserved by the nominal

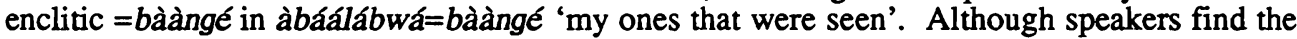
latter construction a bit awkward (and occasionally show inconsistency in the tonal realization), they are in agreement that the final syllable [bwa] must be realized short.
} 
are not subject to. By extension, non-derived nouns such as òmúgwáágwá, èkì wábyò may also be entered in the lexicon with underlying final bimoraic syllables.

There is one final argument in favor of having a rule of FVS apply within NCG's, but not within VCG's. This is that the form undergoing this special FVS rule need not be a lexical noun-it may, in fact, be a possessive enclitic:
a. kìkópò=kyéè=kí
'which cup of his/hers?'
b. kìtàbó=kyè=kí
'which book of his/hers?'
c. kìkópò=kyààbwè=kí
'which cup of theirs?'
d. kìtàbó=kyààbwè=kí
'which book of theirs?'

In (37a) the length on =kyéè 'his/her' is preserved because of its HL falling tone before the nominal enclitic $=k i$ ' $w$ wich'. In $(37 \mathrm{~b})$, on the other hand, $L$ tone $=k y e ̀$ surfaces with a short vowel, though it is followed by the same enclitic. The morphology of =kyè is clear: class $7 \mathrm{ki}$ - followed by the GL -aa- (see note 9) and the third person singular pronominal element $-e$. There can be no doubt, then, that the underlying representation of $=k y e ̀$ is polymoraic. Since there is no HL falling tone on it, as there was in (37a), and since $=k y e$ does not count as a "stem" for the purpose of monosyllabic length, the nominal FVS rule applies to it. The same is seen in (37c, d), where the possessive enclitic 'their' ends in a CGV. Since the [bwe] syllable never acquires a HL falling tone, its underlying bimoraic structure /bue/ will always be subject to nominal FVS. Thus, the same FVS rule applying to deverbal nominals applies as well to pronominals. Before providing an analysis of these facts in $\S 4$, we shall observe in the next section that the situation is quite different in the case of verbs.

\section{FVS in the Verbal Clitic Group (VCG)}

In the preceding section we distinguished three sources of final length on Luganda forms: monosyllabic length, contour tone length, underlying length. It was seen that length due to stem monosyllabicity or a HL contour tone will always be preserved within a NCG, while underlying length (manifested as a surface CGV sequence) is not. In this section we shall consider the fate of these three vowel lengths within the verbal clitic group (VCG), which we now discuss in reverse order.

3.1. Underlying vowel length. We begin by considering verbs whose final CGV sequence suggests an underlying sequence of vowels. Three verbal suffixes frequently produce final underlying length. The first is the passive suffix -u(with its -ibu-/-ebu-variants). As seen in (38), 
(38)

a. kùlábà 'to see'

kùlábwà

'to be seen' (-lab-u-a)

kùlábwàà=kô

'to be seen a little'

kùlábwàà=kí

'to be seen by what?'

b. kùlyâ

'to eat'

kulîibwà

'to be eaten' (-li-ibu-a)

kùlìi bwáá=mû

'to be eaten from' (partitive)

kùlíi bwáá= wá

'to be eaten where?'

the length obtained when a /Cua/ sequence becomes [Cwaa] is preserved when followed by an enclitic.

The second verbal suffix is causative/instrumental -i-. As seen in (39),
a. kùlímá
'to cultivate'
kùlímyá
'to make cultivate' (-lim-i-a)
kùlimyáá=kô
'to make cultivate a little'
b. kùsíbá
'to tie'
kùsíbyá
'to tie with' (-sib-i-a)
kùsíbyáá=kí
'to tie with what?'

the length obtained when a / $\mathrm{Cia} /$ sequence becomes [Cyaa] is also preserved when followed by an enclitic.

Finally, the so-called "modified base" of Luganda, deriving from Proto-Bantu $*_{j} d-e$, provides the third verbal ending. In most cases the proto $* d$ is missing in Luganda, thereby producing a /Cie/ sequence. As seen in (40),

(40) a. tèbálàbá

tèbáálàbyé

tèbáálàbyèè=kô 'they don't see'

'they didn't see' (-lab-i-e)

'they didn't see a little' 
b. tèbátèmá

tèbáátèmyé

tèbáátèmyèè=kí

\author{
'they don't chop' \\ 'they didn't chop' (-tem-i-e) \\ 'what didn't they chop?' (echo Q)
}

this usually results in a [Cyee] ending, whose length is preserved before an enclitic. In cases such as in (41), where the preceding consonant has undergone mutation to $[s]$ or $[z]$, however, there is no surface glide on the modified base:

(41)
a. tèbálèètá
tèbáálèèsé
tèbáálè̀̀sè̀ $=k \hat{o}$
b. tèbásàlá
tèbáásàzé
tèbáásàzèè=kí

\author{
'they don't bring' \\ 'they didn't bring' (-leet-i-e) \\ 'they didn't bring any' \\ 'they don't cut' \\ 'they didn't cut' (-sal-i-e) \\ 'what didn't they cut?' (echo Q)
}

Still, the expected length is preserved before an enclitic. 27

In short, underlying final length will always be realized internally to a VCG. This contrasts sharply with the situation in NCG's. As we saw in §2.3, underlying length does not guarantee surface length on the final syllable of a nominal within a CG. Instead, within the NCG, only contour tone length and monosyllabic length guarantee surface length. As we shall now see, the VCG also diverges from the NCG in the manner in which it treats contour tone length.

3.2. Contour tone length. In (42) we present verbs in the negative of the present and near future tenses:

a. tèbábálâ

tèbábáláà=kô

b. tèbáágúlê

tèbáágúléè=kí 'they don't count'

'they don't do much counting'

'they will not buy'

'what will they not buy?' (echo Q)

${ }^{27}$ All verbs that end in $[\mathrm{sV}]$ or $[\mathrm{zV}]$ show length when a verbal enclitic follows. We assume with Herbert [1976] and Halle and Vergnaud [1980] that the "absorption" of the [y] glide into a preceding $[s]$ or $[z]$ is a late phenomenon (see Ashton et al [1954:153-154] for more on consonant mutation). 
As seen, the verbs end in a HL falling tone which accounts for the length that is realized before the enclitics $=k \hat{o}$ and $=k i$. So far this result is identical to that seen in the NCG.

Where the result is different is seen in (43).
a. àbàlâ
'he who counts'
àbàlá=kô
'he who counts a bit'
b. ànáábálâ
'he who will count'
ànáábálá=kí
'he who will count what?' (echo Q)

In these present and near future relative forms, the verb has a final HL falling tone in isolation. When followed by an enclitic, however, neither the fall nor the length is realized. We saw earlier in (29a) and (30) that contour tone length surfaces within NCG's even when the HL falling tone itself does not. VCG's thus differ from NCG's in requiring a surface falling tone in order to get contour tone length.

The second forms in each pair in (43) lose the L part of the HL falling tone when followed by an enclitic. As a result, the FV of the verb is realized with a $\mathrm{H}$ tone. The tonal alternations seen in (43) are part of a more general process of L tone deletion that applies between H's within a "tone group" (TG), as described by Hyman, Katamba and Walusimbi [1987]. Other examples are given in (44).
a. bábàlá28
'they count'
bábálá=kô
'they count a bit'
b. bánààgúlâ28
'they will buy'
bánáágúlá=kí
'what will they buy?'

The conditions that must be met in order for two forms to join as a single TG are quite complex. Suffice it to say here that an affirmative verb + verbal enclitic constitute such a TG. Since both $=k \hat{o}$ and $=k i$ have a $\mathrm{H}$ tone, the $\mathrm{L}$ is deleted from the underlined vowels in the examples. ${ }^{29}$

${ }^{28}$ The prepausal $\mathrm{H}$ tone on these forms is intonational in nature and, being introduced late in the derivation, is not present at the time $L$ tone deletion applies. Hence, these single word forms are allowed to surface with $L$ surrounded by $H$ 's.

${ }^{29} \mathrm{~L}$ tone deletion does not apply in (38) or in (40-42) since neither an infinitive nor a negative verb joins with the enclitic to form a TG (see Hyman, Katamba and Walusimbi [1987]). 
Finally, the examples in (45) show that the FV of the verb remains long after $\mathrm{L}$ tone deletion applies within a TG, if the length derives not from a final contour, but from an underlying vowel sequence:
a. túlàbwá
'we are seen'
túlábwáá=kô
'we are seen a little'
b. túnáálábwà
'we will be seen'
túnáálábwáá=kí
'what will we be seen by?'

The underlying length of the verb stem /lab-u-a/ 'be seen' is lost at the end of a VCG. Despite the formation of a TG and the application of $L$ tone deletion, this length is not shortened internally to the VCG. We conclude, then, that it is only contour tone length that shows this split behavior on verbs: contour length will surface if the HL contour also surfaces.

3.3. Monosyllabic vowel length. Before presenting our analysis of the above facts in $\S 4$, we have yet to consider the third source of final length: that arising from the requirement that a monosyllabic stem have at least two moras. Since all verbs end in a FV formative $-a$ or $-e, 30$ and since all verb roots have at least one underlying vowel, it follows that all verb stems, including monosyllabic ones, will consist of at least two moras, as seen in (46).
a. kùgwá
'to fall'
(-gu-a)
kùmwá
'to shave' (-mo-a)
kùlyâ
'to eat'
(-li-a)
kùkyâ
'to dawn' (-ke-a)
b. kùbâ
'to be' (-ba-a)
kùtâ
'to let go' (-ta-a)
kùwâ
'to give'
$(-\mathrm{Ca}-\mathrm{a})^{31}$

30Except for part of the conjugation of the verb kùmányá 'to know', e.g. mìmànyî 'I know'.

${ }^{31}$ The [ $\left.w\right]$ of 'give' derives from historical ${ }^{*} p$, which still surfaces in forms such as mpâddé 'I have given'. In the text we simply indicate that the verb root has a $/ \mathrm{Ca} /$ structure. Note that the identity of the vowel of a CV verb root can be determined from different parts of the verb paradigm, e.g. the modified base, which provides not only mìâadde, but also ñgúddè 'I have fallen', ìdî dde 'I have eaten', and so forth. 
c. kùfâ

$$
\begin{aligned}
& \text { 'to die' } \quad(f u-a)^{32} \\
& \text { to grind' } \quad(s e-a)
\end{aligned}
$$

kùsâ

In (46a) the vowel of the root glides to produce a CGV syllable. In (46b) we obtain a CV syllable since the root vowel is $/ a /$, which deletes before another vowel (here also /a/). Finally, in (46c), where we expect the stems *fwa and *sya, we observe that $[w]$ is elided after a labiodental and [y] is elided after a sibilant (cf. (41) above). In all cases, the length of a monosyllabic stem is preserved when followed by a verbal enclitic:

(47)
a. kùgwáá=kô
kùlyáà=kí
b. kùbáà=kô
, kùwáà=kí
c. kùfáà=kô
kùsáá=kí
'to fall on (top of)'
'to eat what?'
'to be on'
'to give what?'
'to be concerned with' (idiomatic)
'to grind what?'

However, this length is not due to the monosyllabicity of these stems, but rather is underlying (and reinforced by a $\mathrm{HL}$ contour tone in some of the examples).

We conclude that there is no example where length could be unambiguously attributed to the monosyllabicity of a verb stem. In order to further support this conclusion, we end with a discussion of the copula $-l i$ which, appearing in certain tenses only, has been said to be a defective verb. If $-l i$ is a verb stem, we would expect it to show monosyllabic length when followed by an enclitic. Concerning -li, Ashton et al [1954:423] state that "lengthening is irregular". We reproduce in (48) their table from the bottom of p. 423 with tone marks added and vowel length explicitly marked:

${ }^{32}$ The verb root 'die' derives historically from $* k y$, where the "superclosed" ${ }^{*} y$ causes labiodentalization of a preceding non-nasal consonant (cf. discussion in Katamba [1974]; Herbert $[1975,1976])$. Nearly all instances of $[f]$ and $[v]$ have this source in Luganda and hence appear only before present-day / $u /$ (whose glided realization [ $w$ ] may be elided). In cases where the labiodental alternates with another consonant, e.g. kùyúliká 'to tear (intr.)' gives rise to the adjective -yùlifiù 'torn', the underlying consonant can be determined. When root internal, as in -fu'die', however, one cannot establish the source of the $[f]$ or $[v]$ on purely synchronic grounds. 
(48) Present Tense

Affirmative

ǹd $\mathrm{i}=m \hat{u}$

$\grave{o} l \grave{l}=m \hat{u}$

àlì=mû

túlí=mû

múl=mû

bálí=mû
Negative

sillìi=mû

tólî̀ $=m \hat{u}$

tálî̀=mû

tètúlî̀=mû

tèmúlî́=mû

tèbálî̀ $=m u ̂$
General Past Tense

Affirmative Negative

ìnàlí=mû $\quad$ sáálì=mû

wàlí $=m \hat{u} \quad$ tèwàlî̀ $=m \hat{u}$

yàlí=mû

twááli=mû

tèyàlî̀i=mû

mwááĺl=mû

báálí=mû tètwáli=mû

tèmwáálì=mû

tèbáálì=mû

'I, you sg., he/she, we, you pl., they \{are in, aren't in, were in, weren't in\}'

In this table the copular forms are given in the present and general past tenses, affirmative and negative. The rows correspond to the six personal pronouns appearing in subject position. A close examination of these forms reveals that length will surface if a HL contour tone is realized on the copula. As in the case of full verb forms (see §3.2), an affirmative copula joins with the following enclitic $=$ mû to form a single TG within which $\mathrm{L}$ tone deletion applies. Thus, the only possibility for a HL contour tone on the copula is in (some of) the negative forms. We now see that length on -li is not irregular, but rather follows the pattern for (verbal) contour tone length in general. In conclusion, -li does not have monosyllabic length, presumably because it is not a verb stem.

\section{An Analysis}

The preceding two sections have produced the following facts concerning final vowel length in (49):

(49) a. A vowel will always be short at the end of a CG.

b. A PW-final 33 vowel will be long within a CG, if

i. the length-bearing $\mathrm{PW}$ is a proclitic, 34

ii. within a NCG the length is due to stem-monosyllabicity or a HL contour tone,

iii. within a VCG the length is underlying or due to a $\mathrm{HL}$ contour tone that is realized on the surface.

In order to account for (49a), we have asserted all along that there is a rule of FVS that applies at the end of a CG. Such a rule cannot account for the facts of

${ }^{33}$ Recall that PW-final means occurring at the end of a phonological word, where the PW may be a full (host) word, a clitic, or other so-called non-affixal "particle".

${ }^{34} \mathrm{We}$ assume that the length on a GL, e.g. byaa=, and on the subject cleft marker, e.g. byee=, is due to the underlying vowel sequences in /bi-aa/ and /bi-ee/, not due to the monosyllabicity of these forms, which are not lexical stems. 
(49b), however. In order to capture the intra-CG length facts, we can either introduce new rules of FVS or we can try to extend the rule of FVS that we already have to the CG-internal environments. Since an analysis with one FVS rule representing a single generalization is to be preferred a priori over an analysis with two or more separate FVS rules, our proposal will be that there is one rule applying not only at the end of a CG, but also at the end of a PW. It is the application of this one FVS rule at the PW level that produces the complex distribution of final lengths within the CG. As we shall see, the introduction of invisibility (extraprosodicity) at the end of a verbal PW produces all of the desired effects.

4.1. Underlying length in the NCG vs. VCG. There are two separate discrepancies in the treatment of FVS within a NCG vs. VCG. First, underlying long vowels are shortened finally on nominals, but not on verbs. Second, contour tone length is shortened on verbs when the HL contour does not surface but is retained on nominals (but see §4.2). We now treat each of these in turn.

The first question to resolve is why FVS applies to the underlying length of nouns, but not verbs. Consider the following examples:
(50) a. kíkòlwá
'deed'
$[k i-k o l-u-a]_{N}$
kíkòlwà=kí
'which deed?'
b. kíkòlwá
'it is done'
$[k i-k o l-u-a]_{\mathrm{V}}$
kíkòlwáá=kí
'what is it done by?'

In both (50a) and (50b), the form kikòlwá consists of a class 7 prefix ki-, the verb -kol- 'do, work', the passive suffix - u-, and the FV -a (cf. discussion in §2.3). However, as seen, underlying length is not preserved before the nominal enclitic $=k i$ ' $w h i c h$ ', but is preserved before the verbal enclitic $=k i$ ' $w$ hat'.

The most concrete solution is one that refers directly to the $\mathrm{N}$ vs. $\mathrm{V}$ distinction, as shown to the right in (50). In this approach, FVS shortens the underlying length of a PW only if it is marked [+N]. This immediately raises the question of why nouns and verbs should differ in just this way, rather than, say, the reverse, with FVS affecting only PW's that are [+V]. In addition, a major drawback of this morphological solution is that it does not lead one to expect that there will be other discrepancies between NCG's and VCG's, e.g. that concerning contour tone length. Since we believe that the two are connected (see below), a phonological solution that reveals this connection is to be preferred.

Since we opt for a phonological solution, our strategy must be to establish phonological representations for nouns and verbs from which the length 
discrepancies follow. One possibility would be for verbs (but not nouns) to be assigned a phonological accent on their last mora, as in (51).
(51)
a. ki-kol-u-a
'deed'
b. ki-kol-u-ä 'it is done'

It would then be stipulated that this accent blocks the application of PW-level FVS on verbs. Note, however, that there is no phonological evidence for such an accent except the length facts we are attempting to account for. Such a verb-final accent is thus nothing more than an ad hoc diacritic. Furthermore, it is of no help in accounting for the differential behavior of nouns vs. verbs in the realization of final contour tone length within a CG.

The same problems are associated with a second attempt, which is to assume different internal structure in nouns vs. verbs. Specifically, we could say that the stem is bracketed off differently in nouns vs. verbs, as shown in (52). 35
(52) a. [ ki- [ kol-u-a ] ]
'deed'
b. [ki- [ [kol-u ]-a ] ]
'it is done'

The intuition we are trying to capture is that the FV of verbs is separated by a stronger boundary from the rest of the word than it is in the case of nouns-even nouns whose FV is a derivational suffix, e.g. mùlimí 'farmer', derived from the verb root -lim- 'cultivate' + the agentive FV -1). In (52a), PW-level FVS applies, since the affected input /ua/ precedes a right bracket (in fact two). In (52b), on the other hand, $/ u /$ and $/ a /$ are interrupted by a right bracket which, according to this analysis, blocks the PW-level application of FVS. While this accounts reasonably well for the data, the representations in (52) again are ad hoc, serving only the purpose of accounting for noun vs. verb realizations of underlying final length. Also, as in the preceding analyses, the device of bracketing does not straightforwardly account for noun vs. verb differences in the realization of contour tone length. By contrast, the analysis that we shall now present accounts for all noun/verb length discrepancies in a natural way.

We propose an analysis in terms of "invisibility", a term that Poser [1984] and Inkelas [1989] give to the various manifestations of extraprosodicity (extrametricality, extratonality, etc.). Specifically, the FV of verbs (but not nouns) is invisible, as shown by the parentheses in (53b):

35Bantuists traditionally apply the term stem to the span that goes from the verb root to the end of the word. The part of the stem that precedes the final vowel is called the base (see, for instance, Meeussen [1967]). In (52) the claim is made that the base is phonologically relevant (exists?) only in verbs, not in nouns. 

a. ki-kol-u-a
'deed'
b. $k i-k o l-u(-a)$
'it is done'

PW-level FVS will apply in (53a), since final length is always visible in nouns. In (53b), on the other hand, PW-level FVS will not apply, since the last visible vowel is $/ u /$, which is short. This solution utilizes a device frequently needed in prosodic analysis. That invisibility should be restricted to a specific morphological class (verbs) should not be surprising, since the most famous application of invisibility (English stress), must also recognize a noun/verb dichotomy [Hayes 1982]. The present application is well-formed, given that it obeys Hayes' peripherality condition. Since the verb form in (53b) is realized with a final short vowel when not followed by an enclitic, we assume that invisibility is removed at the CG level, where we know FVS applies without regard to grammatical category (cf. (49a)). ${ }^{36}$

4.2. Contour tone length in the NCG vs. VCG. There are many more issues that arise in connection with the above proposal, e.g. how does invisibility of the FV of verbs affect the rest of the phonology? Rather than going into that issue now, we first show that unlike other solutions, invisibility readily accounts for the differential effects of FVS not only on underlying length, but also on contour tone length.

From data such as in (54a), it will be recalled that contour tone length is always realized within a NCG, whether or not the HL contour is itself realized on the surface:
a. kìsìkî
'log'
lì sìkî̀=kí
'which log?'
kìsì kíi=kyàngé
'my log'
b. tágúlâ
'he doesn't buy'
tágúláà=kô
'he doesn't buy any'

36 According to Inkelas' [1989] interpretation of invisibility, the final vowel of a Luganda verb is invisible because it is not part of the PW at all, as in the following prosodic bracketings:

(i) $\left.[\text { [ ki-kolu-a }]_{P W}\right]_{C G}$ 'deed'

(ii) $\left[[\text { ki-kolu }]_{\mathrm{PW}}^{-a}\right]_{\mathrm{CG}} \quad$ 'it is done'

As can be seen, FVS would apply to the noun form at the PW level, but not to the verb form, where the final vowel -a lies outside the PW. If no enclitic is added, the verb form will undergo FVS at the CG level. Note that the above representations give a principled basis to the bracketing analysis we just rejected. 
$\begin{array}{ll}\text { c. àgùlâ } & \text { 'he who buys' } \\ \text { àgùlá=kô } & \text { 'he who buys a bit' }\end{array}$

In (54b) we see that contour tone length is preserved within a VCG when the HL contour itself also surfaces. In (54c), however, where the $\mathrm{HL}$ is not realized, we obtain a surface short vowel on the verb.

The first question is why the PW-level FVS rule fails to shorten contour tone length on nouns. Recall from (29) that contour tone length results from the interaction of two rules: (1) L tone insertion (applying whenever the last $\mathrm{H}$ of a word is not followed by a L) and (2) mora insertion (applying whenever there is no mora for the inserted $L$ to link to, i.e. whenever the $\mathrm{H}$ is on the last mora of the word). In order to preserve contour tone length within a NCG, the natural move to make is to order L tone insertion and mora insertion to follow the PWlevel application of FVS, as in (55).
a. [ [ kisiki $\left.]_{\mathrm{PW}}[k i]_{\mathrm{PW}}\right]_{\mathrm{CG}}$
PW-LEVEL RULES:
$\mathrm{H}$
$\mathrm{H}$
FVS (inapplicable)
$\begin{array}{rr}\text { b. [ kisiki ] } & {[k i \text { ] }} \\ \mathrm{HL} & \mathrm{HL}\end{array}$
L-tone insertion
Mora insertion

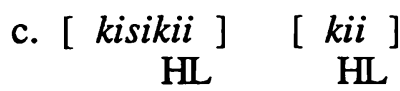

The output of (55) is then subjected to the CG-level application of FVS and the vowel of the enclitic $=k i$ is shortened. 37

Although it works for a VCG such as in (54b), where both the HL contour and the length are preserved, we do not think that the same derivation applies to verbs. In order to see why, consider the following representation of the VCG in $(54 c)$ :
a. $\left[[\text { a-gul (-a) }]_{P W}[k o]_{P W}\right]_{C G}$
PW-LEVEL RULES:
$\mathrm{H} \quad \mathrm{H}$
FVS (inapplicable)
b. $[$ a-gul (-a)]
[ $k o$ ]
L-tone insertion
$\mathrm{HL}$
$\mathrm{HL}$

37Its $\mathrm{HL}$ tone is also modified to $\mathrm{H}$ as in WH-intonation [Stevick 1969:27]. 

c. $\left[\begin{array}{lll}\text { a-gul }(-a)] & {[\mathrm{koo}] \quad \text { Mora insertion }}\end{array}\right.$
$\mathrm{HL} \quad \mathrm{HL}$
d. [ a-gul-a
koo ]
CG-LEVEL RULES:
$\mathrm{HL}$
$\mathrm{HL}$
e. [ a-gul-a
ko ]
FVS
$\mathrm{HL}$
$\mathrm{HL}$
f. [ à-gùl-á
$k \hat{o}$ ]
L-tone deletion
$\mathrm{H}$
$\mathrm{HL}$

In (56a), the FV of the verb is marked invisible. In (56b), L-tone insertion applies twice, since its only requirement is that the last tone of the $\mathrm{PW}$ be $\mathrm{H}$. For L-tone insertion to apply to the verbal PW, we assume that the tone is visible, while the mora/V-slot is not. Because invisibility prevents it from seeing that this $\mathrm{H}$ is linked to a final mora, mora insertion cannot apply to the verb, although it does apply to the enclitic in (56c). In (56d) we see the invisibility has been removed, since it now occurs nonperipherally within the CG. CG-level FVS applies to the enclitic in (56e) and, finally, in (56f), a rule of L-tone deletion removes the floating $L$ that appears between two H's within a TG (see Hyman, Katamba and Walusimbi [1987]).

Now, returning to the VCG in (54b), the derivation proceeds as in (57):
a. $\left[[t \text {-a-gul (-a) }]_{\mathrm{PW}}[k o]_{\mathrm{PW}}\right]_{\mathrm{CG}}$
PW-LEVEL RULES:
$\mathrm{H}$
$\mathrm{H}$
b. [ $t-a-g u l(-a)]$
[ $k o$ ]
L-tone insertion
$\mathrm{HL}$
$\mathrm{HL}$
c. [ $t$-a-gul (-a) ]
[ $k o o$ ]
Mora insertion
$\mathrm{HL}$
$\mathrm{HL}$
d. [ t-a-gul-a
koo ]
CG-LEVEL RULES:
$\mathrm{HL}$
HL
e. [ $t$-a-gul-a
ko ]
FVS
$\mathrm{HL}$
HL
f. [ t-á-gúl-áà
kô ]
Mora insertion
$\mathrm{HL}$
$\mathrm{HL}$

FVS (inapplicable) 
In (57a) the FV of the verb is marked invisible. In (57b) L-tone insertion applies to both PW's, and in (57c) mora insertion applies to the enclitic $=k o o$, but not to the verb. This yields the CG-level representation in (57d), where invisibility has been removed. CG-level FVS applies to shorten the long vowel of the enclitic in (57e). Note that L-tone deletion cannot apply to (57e) because a negative verb does not form a TG with what follows it (Hyman, Katamba and Walusimbi [1987]). Instead, mora insertion applies internally to the CG, yielding a long vowel with a $\mathrm{HL}$ contour in (57f). With this derivation we see that invisibility accounts for all of the noun/verb differences in the realization of final length.

4.3. Monosyllabic length. So far we have accounted for the realization of underlying length and contour tone length. We still need to explain why PW-level FVS does not apply to monosyllabic noun stems. 38 Since the FV of nouns is not invisible, a representation such as /kì-déé/ 'bell' would automatically become [kì-dé], and we would obtain CG realizations such as *kìdé =kí 'which bell?'. However, the correct realization is kìdéé =kí, so we must find a way to exempt monosyllabic stems from FVS at the PW level.

There are two logical possibilities. The first is to assume a rule ordering solution as was proposed for contour tone length: PW-level FVS does not apply to monosyllabic noun stems, because they have a short vowel at the point where the rule applies. This analysis necessarily commits us to the view that the vowel of monosyllabic noun stems is underlyingly short, e.g. /-de/ 'bell'. That this cannot account for all of the data is seen from morphologically complex monosyllabic nouns stems, such as in (58).
(58) a. mùmwí
'barber'
(cf. kùmwá 'to shave')
mùsí
'miller'
(cf. kùsá 'to grind')
b. mùmwík=kí
'which barber?'
mùsîi=kí
'which miller?'

The deverbal noun stems in (58a) have the underlying structures /mo-i/and /se-i/, where $-i$ is an agentive FV morpheme. 39 As seen in (58b), the length of these

38Recall from $\$ 3.3$ that the issue of monosyllabicity does not arise in verbs, since all monosyllabic verb stems have the structure CV + FV and hence underlying length, which will always be preserved within a CG.

${ }^{39}$ Recall from (6) and $\$ 3.1$ that high vowels glide before another vowel and produce compensatory lengthening. Within a stem, however, $/ e /$ and $/ o /$ also glide, as seen in the verb stems -mwa 'shave' and -sa 'grind'. As also was exemplified in \$3.1, the expected [y] glide in the latter form is elided because of the preceding sibilant. 
monosyllables is preserved before the nominal enclitic $=k \hat{i}$. These stems clearly have a bimoraic underlying structure of two different vowels in sequence. If FVS first applies, it will therefore delete the second mora, leaving the vowel [i] floating. Since a long vowel is required on the surface, the second mora will have to be put back by an insertion rule that undoes the first rule.

Given the roundabout complexity of the rule ordering account (cf. also note 41), an alternative is to adopt the suggestion of Hyman [1989] that there is an accent on the second mora (M2) of every stem which exempts it from shortening at the PW-level:40

(59)
a. $[m u-[m o-i]]$
b. [mu-[se-**i ] ]
c. $[k i-[\text { de-e }]]^{41}$

Since Hyman presents five separate arguments for this M2 accent, we need not worry that the asterisk is an unmotivated diacritic. Assuming this second stemmora accent, our analysis can account for all of the final length data presented thus far. .2 The question which we shall raise in the next section is whether it can be extended to account for the rest of the language.

\section{FVS in Other Constructions}

In the preceding sections we have presented and analyzed the facts of FVS within NCG's and VCG's. In this section we test our results against other parts of the grammar of Luganda where there are complexities in the realization of final

40This exemption would be visible only to PW-level FVS, since all long vowels are shortened by CG-level FVS.

${ }^{41}$ In this analysis also, 'bell' and other such non-derived stems could technically be set up with either one or two underlying moras. One could argue for the one mora solution on the basis that the second stem mora is redundant and should thus not appear in lexical entries. However, this solution necessitates a separate rule of mora insertion for monosyllabic stems that is not needed in the two mora analysis. Note that there are other possible interpretations, given the parameters we have introduced. One could assume, for example, the bimoraic representations /-mo-i/ 'shaver' and /-dee/ 'bell', which first undergo PW-level FVS (which deletes the moraic support, but not the vowel phoneme) and then are subject to the additional mora insertion rule affecting monosyllabic stems. For reasons of simplicity, we choose the solution presented in the text.

${ }^{42} \mathrm{We}$ would like to point out also that proclitics such as the GL do not undergo PW-level FVS because (for the purposes of FVS) proclitics are not PW's. This is motivated by the facts of TG formation. While TG's are formed on a word by word basis in Luganda (see Hyman [1988]), the one exception is that any number of proclitics join the host to constitute a single word for this purpose. The situation is actually more complex than this. Since the tone rules themselves require that proclitics be treated differently from prefixes, we apparently need to specify them as distinct both from PW's and from affixes. 
length. As we shall see, there is considerable generality to the conclusions we have reached thus far. We begin with adjectives and then treat compounds and reduplications.

5.1. Adjectives. In $\S 2$ we found that nouns and pronouns follow the same pattern with respect to FVS. In $\$ 3$ we saw that verbs follow another pattern. We have not yet examined other parts of speech in Luganda. One reason is that some of these are never followed by an enclitic. Thus, we cannot know for sure if the underlying length of demonstratives such as in (60a) or the contour tone length of those in $(60 \mathrm{~b})$ would be preserved before an enclitic:
(60) a. kìkópò èkyó
lùggí òlwó
'that cup' (near hearer) /e-ki-o/
báàná àbó
'that door'
|o-lu-o|
'those children'
|a-ba-ol
b. kìkópò kìlî
'that cup' (yonder)
|ki-li/
lùggí lúlî
'that door'
/lu-li/
báánà bàlî
'those children'
|ba-li/
c. kìkópò kìnó
'this cup'
/ki-nol
lùggí lùnó
'this door'
/lu-no/
báàná bànó
'these children'
|ba-no/

It also is not possible to tell whether any of the demonstrative stems, e.g. /-no/ in (60c), would show monosyllabic length, since, as we have just said, demonstratives occur finally within their CG. 43

We can test adjectives (and to some extent numerals) for their final length properties. As has often been noted in many Bantu languages, adjectives show most or all of the morphological properties of nouns, e.g. the same ("primary") noun class prefixes. While adjectives are scarce in some Bantu languages, they are quite plentiful in Luganda, many of the adjective stems being derived from a corresponding verb root plus a FV $-u$ or $-e$ :

${ }^{43}$ On the other hand, it is possible to find proclitics preceding almost any part of speech, e.g. kikóṕ kyáá=bàn 'cup of these (e.g. children)', byèè= binó 'it's these', etc. These cases are of limited interest, however, since it is the length of the proclitic that occurs internally to the CG (as expected), not that on the demonstrative. 


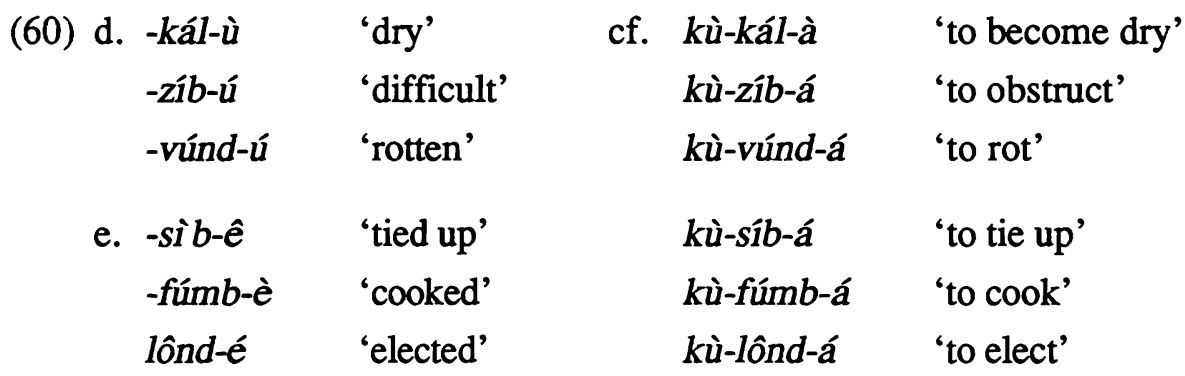

In the following two subsections we shall examine the final length properties of adjectives first in the NCG, then in the VCG.

5.1.1. FVS on adjectives in the NCG. In (61) we provide three adjectives followed by the nominal enclitic $=k i$ ' $w h i c h$ ':
a. kìkópò kìsáá=kí
'which empty cup?'
b. kìkópò kìgùmúùu=kí
'which durable cup?'
c. mùkázì mwààgálwà=kí
'which beloved woman?'

In (61a) the adjective stem -sá 'empty' shows monosyllabic length before =kí In (61b), -gùmû 'durable' shows length on the surface HL contour tone. Finally, in (61c), the adjective -àgálwà fails to realize its underlying length. This is particularly noteworthy, since this adjective is derived from the passive verb stem -agal-u-a 'to be loved', which provides two underlying moras: the passive suffix $-u$ - and the FV -a. Despite this, FVS applies at the PW-level and we obtain the short FV on the adjective in (61c). 44

The same length phenomena are observed in (62), where each of the three adjectives is directly followed by a possessive enclitic: 45

\footnotetext{
${ }^{44}$ Similar examples showing shortening of underlying length include:

(i) mùkázì mwéésìgwá=kí 'which trustworthy woman?'

(ii) màtá mábúgùmyè=kí 'which warm milk?'
}

In (i) the source verb consists of the reflexive -ee-prefix plus a verb stem -sig-u-a, meaning 'to be trustworthy', where -u-again is the passive suffix (cf. -éé-sìg-á 'to trust', without the passive suffix). In (ii) the source verb is -búgùm-i-a 'to cause to be warm', where - $i$ - is the causative suffix (cf. -búgùm-a 'to be warm'). See also the infinitive forms in (67).

45The reason for not including the head noun in these examples is that the enclitic would have to immediately follow it: kikopò̀=kyàngè kìsá 'my empty cup'. The reverse order, *kìkópò kìsá kyàngé, is ungrammatical. Instead, an augment vowel would be required, in which case it would no longer be an enclitic (kìkóò kìsá ékyângé 'my empty cup which...'). As seen from the gloss, the phrase needs to be completed, e.g. by a relative clause. 

a. kìsáá=kyàngé
'my empty one'
b. kìgùmúú=kyàngé
'my durable one'
c. mwààgálwà=wàngé
'my beloved'

Monosyllabic length is preserved in $(62 \mathrm{a})$; contour tone length is preserved in (62b), even though the HL contour is not; and in (62c), we again see that underlying length is not preserved on an adjective within a NCG.

The facts in (61) and (62) mirror exactly those seen for nouns in $\$ 2$. The analysis provided in $\$ 4$ for NCG's thus holds also when the host is an adjective.

5.1.2. FVS on adjectives in the VCG. Although adjectives are morphologically nouns (and thus share a $[+\mathrm{N}]$ feature), unlike nouns, they potentially can host verbal enclitics, specifically the locative enclitics $=k \hat{o}$ and $=m \hat{u} .46$ We saw in $\$ 1.2$ that these enclitics can have an attenuative effect on the action of a verb, e.g. 'to buy a little, to see a bit' etc. As seen now in (63), =kô and =mû have the same attenuative effect on adjectives:
a. kyéélú=kô
'rather white'
(-éèlú
'white')
kìtélévú=kô
'rather straight'
(-télèvi
'straight')
kìtálávvú=kô
'rather rusty'
(-tálàvvú 'rusty')
b. kìzító=mû
'rather heavy'
(-zító
'heavy')
kìyónjó=mû
'rather clean'
(-yónjò
'clean')
kìwánvú=mû 'rather high'
(-wánvù
'high')

The adjectives in (63) are given with a class $7 \mathrm{ki}$ - prefix. Some adjectives can only take one or the other enclitic, while others can take either one. For the purpose of determining the effects these enclitics have on the final length of adjectives, we cite adjectives with $=m \hat{u}$.

The example in (64a) shows that monosyllabic length is preserved on adjectives not only before a nominal enclitic, but also before a verbal enclitic:

\footnotetext{
${ }^{46}$ Speakers generally accept $=k \hat{o}$ or $=m u ̂$ on some but not all adjectives. All of our consultants, however, were able to provide judgments on how a long list of adjectives would be pronounced if followed by one of these enclitics. Perhaps some of the variation we obtained is due to the fact that many such combinations are rare, if not questionable. Another factor, we believe, has to do with whether speakers view these adjectives as nouns or verbs when followed by $=k \hat{o}$ or $=m \hat{u}, a$ decision that will affect whether the FV is invisible, as we have seen.
} 

(64) a. kìsáá=mû
'rather empty' 47
(-sá 'empty')
b. kìbí=mû
'rather bad'
(-bî̀ 'bad')
kìbî̀=mû
c. kìtóò =mû
'rather young'
(-tô 'young')
kìtóó=mû

As seen in $(64 \mathrm{~b}, \mathrm{c})$, the length of monosyllabic adjective stems having a $\mathrm{HL}$ contour is also preserved before $=m \hat{u}$, whether or not the HL itself surfaces. 48 This too is consistent with the nominal facts. However, consider now the realization of final length on the adjectives in (65).
a. kìgàzî́=mû
'rather wide'
(-gàzî 'wide')
kìgàzíí=mû
kìgàzímû
b. kìgìmúù=mû
'rather fertile'
(-gìmû 'fertile')
kìgìmúú=mû
kìgìmú=mû
c. kìlàmúú=mû 'rather healthy' (-làmû 'healthy')
kìlàmúú $=m u ̂$
kìlàmí $=m \hat{u}$

As seen, when a HL contour falls on the last syllable of a bisyllabic adjective stem, there are three possible realizations: long vowel with HL contour (if CG is treated as two TG's), long vowel with $\mathrm{H}$ tone or short vowel with $\mathrm{H}$ tone (the latter two realizations both treating the CG as one TG). 49 The first two

${ }^{47}$ Although this phrase is phonologically well-formed, it is semantically odd in Luganda, since something is either empty or it is not. Unfortunately, all of the other monosyllabic adjective stems have an underlying $\mathrm{H}$ tone which develops a $\mathrm{HL}$ tone, as seen in $(64 \mathrm{~b}, \mathrm{c})$. In these latter examples final length can be attributed either to the monosyllabicity of the adjective stem or to its HL contour tone.

48Whether an adjective $+k \hat{o} / m u$ will be a single TG (with $\mathrm{L}$ tone deletion) depends on a number of factors. In (63) it can be seen that a single TG is formed whenever the adjective has an internal $\mathrm{H}$ to $\mathrm{L}$ pitch drop in isolation. Whenever there is a $\mathrm{HL}$ contour on the last syllable of the adjective, however, speakers treat these forms in a number of ways, as indicated in the examples cited in this section.

${ }^{49}$ The fourth possibility, where there is a final short vowel, but two TG's, e.g. *kìgàzi $=!$ mû $(!=$ tonal downstep caused by unlinked $L$ tone) has not been attested. Note in the following examples 
realizations are not surprising. The third, however, seems to require that these adjectives be treated with their FV invisible, as was proposed for verbs in $\$ 4$.

Now compare the realization of underlying length on the adjectives in (66).
a. kìkámbwé=mû
'rather fierce'
(-kámbwé 'fierce')
b. kìuúgúmyéé=mû
'rather warm'
(-búgùmyé
'warm')
kyààgálwáá=mû
'rather loved'
(-àgálwà
'loved')
kyéésígwáá=mû
'rather faithful'
(-ésìgwá
'faithful')

The adjective -kámbwé 'fierce' is produced without variation with a final short vowel, as in (66a). The remaining adjectives in (66b) must be realized with length before $=$ mû. The difference between these is that $-k a$ mbwé is not a deverbal adjective, whereas the others are, as seen in the corresponding infinitive forms in (67).
a. kùbúgùmá
'to be warm'
kùbúgùmyá
'to warm'
|-bugum-i-a/
b. kwààgálá
'to like, love'
kwààgálwá
'to be liked, loved'
$\mid$-agal-u-a|
c. kwéésìgá
'to trust'
kwéésìgwá
'to be trusted'
|-ee-sig-u-al

From these forms it can be seen also that the underlying length of the deverbal adjectives derives from the $-i$ - causative or the $-u$ - passive followed by the FV -a. It thus appears that this FV too must be marked invisible in the derived adjectives as in the corresponding verbs. We must assume that the FV of -kámbwé is

that when the final $\mathrm{HL}$ is preceded by a $\mathrm{H}$ tone, the adjective + enclitic must be treated as two TG's:
(i) kìúndáà=mû *kìfúndáá=mû
*kìfúndá=mû
'rather narrow' (-fúndâ 'narrow')
(ii) kìsilíséè $=m \hat{u}$ *kìsilisét =mû
*kìsilísé=mû
'rather quiet' (-sílisê 'quiet')

One speaker did provide the alternate form kifúndá=! mû, i.e. two TG's, with FVS applying to the adjective. Since she did not give the same pronunciation for other adjectives with comparable tone patterns, it is hard to know how to interpret this form. 
visible (and hence subject to PW-level FVS), because it does not have a verbal source. 50

To summarize our findings, adjectives exhibit the same length properties as nouns when they appear in a NCG. In a VCG, on the other hand, there is some variation. We have suggested (cf. note 46) that some of this is due to the marked nature of the construction (adjective $=m \hat{u}$, adjective $=k \hat{o}$ ). This and the whole question of how adjectives should be analyzed in general result in speakers in some cases not being sure whether to apply the nominal pattern or the verbal pattern to FVS. This is clearest in the data in (65), where the second line of each triplet is the NCG realization and the third line is the VCG realization. Of course, the first realization with a long HL contour tone on the surface, is consistent with FVS in both types of CG's. As we shall see in the next section, there is less variation in the realization of final vowel length on compounds.

5.2. Compounds. In this section we shall investigate the length properties of compounds. By compound we shall mean any syntactically complex nominal that can stand for a noun. Frequently this means a $\mathrm{N}+\mathrm{N}$ compound, but, in fact, as seen in the examples in (68),
(68) a. mùgénzí - tázzê
'delinquent debtor' (lit. traveler hasn't returned)
b. mwáámì - àkóóyè
'easy chair' (lit. chief has tired)
c. kyáálà - kímpáddè
'thief' (lit. fingernail has given me)

the source of the complex nominal ("compound") may be a complete sentence, as seen also in the proper names in (69) from proverbs:
(69) a. ǹsí - yàléètá
(lit. country brought)
b. túliná - ómùbéèzí
(lit. we have a helper)
c. sîlì vá - kùnó
(lit. I will not leave here)

In cases such as (68) and (69), where the nominals have an overt sentential structure, the realization of final length internal to the compound will be exactly as it would have been in the corresponding sentence. The noun ǹsî 'country' in (69a) has two reasons for being long: its stem is monosyllabic, and it has a $\mathrm{HL}$ contour tone. As seen, however, it is realized short, because it is not followed by

50Although we have not found speakers who realized the CG's in (66b) with a final short vowel on the adjective, the following tonal variants have been noted:
(i) kyààgálwàà=mû
(ii) kyésìgwàà $=m \hat{u}$
'rather loved'
'rather faithful'

Here the single CG is treated as two TG's, each with its own $\mathrm{H}$ to $\mathrm{L}$ pitch drop. 
an enclitic within the compound. Similarly, in (69c), the verb stem is /vu-a / 'leave', whose underlying (and monosyllabic) length fails to surface because it is followed by a full word, not an enclitic.

This result can be contrasted with the preservation of pre-enclitic length in the following compounds:
a. ǹdábílwáá=mû
'mirror' (lit. I am seen in it)
b. wáálábyèè=kí
(proper name-lit. what have you seen yet)
c. Iwé - múbáá=wô
(proper name-lit. [day] when I am there)

In $(70 \mathrm{a}, \mathrm{b})$ underlying length is preserved on the verb; in (70c), the verb stem is /ba-a/ 'be', which has both underlying and monosyllabic length. Finally, (71a,b) show the corresponding preservation of length on a proclitic:
a. kyàà=kùlábì lá=kô
'example' (lit. that to see from)
b. zàà=bàsâjjá
(proper name-lit. those of the men) 51
c. gwè - bátákígámbyê
(proper name-one that they haven't said it to)

In (71c), however, the underlying length on /gu-e/ is not preserved, since, as we saw in $§ 1.1$, non-subject cleft and relative markers are not phonological proclitics (cf. (12) above). 52

As seen now in (72),
a. mùlwá - kújjúlá
'woman slow to serve food' delayer to serve food
b. kàtwé - kàsá small head empty
'stupid person'
c. ìkyá - mùzí
morning small root
'type of bark-cloth tree'

the first of two nominals (noun, adjective, infinitive) ends short, despite the monosyllabicity and underlying length and, in (72b,c), the HL contour of the

51 We know from the tone that the noun bàsâjja 'men' is appearing here without the augment vowel a- (cf. èzáá=ábàsâjjá, with both parts augmented).

$52 \mathrm{We}$ do have one example in our corpus of over 400 compounds that shows length variation on a relative clause marker: $k y \grave{e}(\grave{e})$ - wàlyângá (proper name-lit. that which you used to eat). Interestingly, the length is possible only in the proper name usage of this form and does not appear in the proverb from which the name is taken (or, of course, in literal speech where it is not a name). 
noun in isolation (kàtwê 'small head', ìkyâ 'morning'). All of the above cited compounds must, of course, be listed in the lexicon. In the noun + noun compounds which we have productively created in (73),
a. mùlyá - màtóóké
'plantain-eater'
eater plantains
b. mùnywá - mwèngé 'beer-drinker'
drinker beer
c. mùmwá - mítwê
shaver heads
'head-shaver'

the first noun again shows a final short vowel. Since monosyllabic stems are exempt from PW-level FVS, as we saw in $\S 4.3$, it would not work to say that the forms in (72) and (73) have two PW's forming a single CG. We therefore conclude that such compounds consist of two CG's, with CG-level FVS removing the final length of the first nominal in all cases. 53

Having established that internal final length in compounds behaves as one would expect from the analysis in $\S 4$, we now consider the realization of final length on the second part of the compound, when followed by an enclitic. Because all compounds are nominal, i.e. there are no compound verbs, we are limited to examining enclitics within the NCG.

We begin by considering compounds where the second member ends in a HL falling tone that is realized before the enclitic $=k i$ ' $w h i c h$ ':
a. mùgénzí - tázzéè=kí
traveller hasn't returned

'which delinquent debtor?'

${ }^{53} \mathrm{We}$ have, however, found the following exceptions which, we assume, must be listed as such (and curiously both involve the same first member):

(i) kìnywáa - bwîno

(ii) kìnywáá - mù=nté 'blotting paper' (lit. drinker + ink)

'tick bird' (lit. drinker from cattle)

In addition, there is the form kàtwéé-wùngú 'madness, folly', which consists of kàtwê 'small head' + a non-independently occurring base whose derivative is seen in the verb kùwúngútúká 'to be null and void, mentally deficient'. Perhaps there has been a reanalysis of this compound into a single CG, given that - wungu does not exist on its own. Finally, there is the interesting case of the mùlyáa - záá=máànyí 'swindler, a cheat' (lit. eater those-of strength). Here it is the length on mùlyaa- that is surprising. Note that the FV of the word máànyí 'strength' is homophonous with the -i deverbal agentive morpheme (e.g. -lim- 'cultivate', mùlimí 'farmer'). As a result, Luganda speakers back-formed a verb kùlyáàzáámáányá 'to swindle' whóse tones unambiguously indicate that it is a single PW. Perhaps it is this interplay that leads to the unexpected length on [lyaa] on the noun form. 

b. kàmàlá - byònnáà=kí
'which Prime Minister?'
finisher everything
(e.g. where the buck stops)
c. ǹnámpá - wè - ǹgwáà=kí
Mr. nowhere that I fall
'which neutral person?'
(i.e. a fence-sitter)

However, if the falling tone does not surface, e.g. preceding a possessive enclitic, speakers vary and tend to accept both realizations of the final vowel on the compound:

(75)
a. mùgénzí - tázzé(ê)=wàngé
'my delinquent debtor'
b. kàmàlá - byònná( $\hat{a})=$ wàngé
'my Prime Minister'
c. ̀̀námpá - wè - ǹgwá(â)=wàngé
'my neutral person'

The same facts are observed when the compounds are productively formed, as in (76).

(76)
a. mùtémá - bísíkî
'log-chopper' (lit. chopper + logs)
b. mùtémá bísíkî̀=kí
'which log-chopper?'
c. mùtémá bísíkîi $(\hat{i})=$ wàngé
'my log-chopper'

We already pointed out that there is variation of just this sort on non-compounds (see note 24). So again, there is no surprise.

The major surprise comes from the realization of monosyllabic length not supported by a (surfacing or non-surfacing) falling tone. As seen in (77),

(77) a. kìnywáá-mù=nté

kìnywáá-mù=nté(e) $=k i ́$

kìnywáá-mù=nté(e)=kyàngé

b. ǹkyá-mùzí

ǹkyá-mùzí( $(\hat{)}=k \hat{i}$

ǹkyá-mùzî(i)=yàngé 'tick bird'

(lit. drinker from cattle-cf. fn. 53)

'which tick bird?'

'my tick bird'

'type of bark-cloth tree'

'which bark-cloth tree?'

'my bark-cloth tree' 
c. mùtúndá-bídé

mùtúndá-bídé(ê)=kí

mùtúndá-bídé(ê)=wàngé 'bell-seller' (lit. seller + bells)

'which bell-seller?'54

'my bell-seller'

the stems -té 'cow', -zi 'small root', and -dé 'bell' appear either long or short as second part of a compound followed by a nominal enclitic. As will be recalled from §2.1, such monosyllabic noun stems must appear long before these enclitics when not in a compound. It thus appears that the monosyllabicity of a noun stem in second position in a compound is not always "accessible", as far as length goes. The facts are the same whether the compounds are lexicalized, as in $(77 \mathrm{a}, \mathrm{b})$, or whether they are newly created, as in (77c). However, we have found that compounds that are names almost never realize length on a final monosyllabic syllable, as seen in $(78 \mathrm{a}, \mathrm{b})$ :

(78)
a. kíttà-èngó
kíttà-èngó=kí
kíttà-èngó=wàngé
b. àkìsá-ènté
àkìsá-ènté=kí
àkìsá-ènté= wàngé
c. mùzâddè-tályà
mùzâddè-tályà=kí
mùzâddè-tályà=wàngé
(proper name-lit. it kills leopard)
'which K.?'
'my K.'
(proper name-lit. he who hides cow)
'which A.?'
'my A.'
(proper name-lit. parent doesn't eat)
'which M.?'
'my M.'

The same is true when the last form in the compound is not a noun, as in (78c). 55 This example also shows what we have known all along, namely that underlying length is not realized before a nominal enclitic (\$2.3).

The issue we now face is how to account for the observed variation. One approach that must be rejected from the start is the idea that $=k i$ and the possessives are sometimes enclitic, sometimes not, and that length differences follow from this. The reason is that a surfacing compound-final HL contour

${ }^{54}$ The realization with a long vowel [bídée] gives the impression that it is the bells that are being questioned, i.e. 'seller of which bells?'

55 Because of the nominal status of the compound, the only reason for expecting length on the verb stem -lyà in (78c) is its monosyllabicity. However, we have to admit that we never were able to demonstrate beyond a doubt that monosyllabicity plays a role in determining vowel length on verb stems. 
always requires a long vowel before $=k i$, as we saw in (74). Thus, we would have to say that the clitic/non-clitic distinction depends on the tonal configuration of the host: =ki would be obligatorily enclitic on compounds that end in a surface HL contour; both $=k i$ and the possessives would be optionally enclitic on compounds that end either in a (non-surfacing) HL contour or a monosyllabic stem. Since we have not yet seen such conditions on cliticization, we judge this solution to be undesirable.

Assuming that we can account for the variable duration of non-realized contour tone length (cf. note 24), this leaves monosyllabic length to be accounted for. Consider a simple (productive) compound such as we saw in (77c), which, informally, has the structure in (79).

(79)

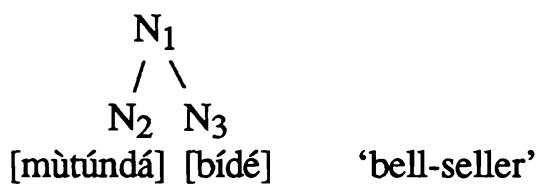

As seen, a single compound $\mathrm{N}_{1}$ is composed of the two simplex nouns mùtúndá 'seller' $\left(\mathrm{N}_{2}\right)$ and bì dé 'bells' $\left(\mathrm{N}_{3}\right)$. The enclitics =kí 'which' and wàngé 'my' (class 1) have been called "nominal" because they are syntactically subcategorized to attach to a nominal immediately to their left, in this case $\mathrm{N}_{1}$. Phonologically, however, such enclitics form a CG with a host full word that occurs immediately to their left, in this case $\mathrm{N}_{3}$. It should be clear, then, that the variation is caused by the non-isomorphism of the syntactic and phonological hosts $\left(\mathrm{N}_{1} \mathrm{vs} . \mathrm{N}_{3}\right)$. No all or nothing principle can in itself account for the variable length realization in forms such as $(77 \mathrm{c})$. However, what we can say is that the more transparent the bond between the internal elements of the compound, the more likely speakers will accept a bimoraic realization of a compound-final monosyllabic stem.

The internal structure of a compound is maximally transparent when the compound is productively created. Examples such as mùtúndá-bíd éé=wàngé 'my bell-seller' are apparently always acceptable with the indicated length. Names, on the other hand, rarely if ever show monosyllabic length, as we saw in (78). This presumably means that in everyday speech speakers do not normally decompose names into their grammatical parts, though etymologies can frequently be provided upon demand. Finally, consider the forms in (80).

(80) a. ìnùmyá-mùtwé

ìnùmyá-mùtwé=kí

ìnùmyá-mùtwè=wàngé 'solid person'

'which solid person?'

'my solid person' 
b. ǹjògélà-mìbí

ǹjògélà-mìbì $=k i ́$

ǹjògélà-mìbì=yàngé 'bad talking'

'which bad talking?'

'my bad talking'

In (80) the first member of the compound is underlyingly toneless (cf. kùgúmyá 'to make solid', kwòògélá 'to talk'56), while the second part of each compound ends in a monosyllabic stem which, in isolation, would have carried a falling tone, i.e. mùtwê 'head', ṁbî 'bad' (class 9). Two things correlate here. First, the underlying $\mathrm{H}$ of the final syllable $(-t w \hat{e},-b \hat{i})$ is realized on the second mora of the first noun stem (exactly as it would be realized if it were a suffixal $\mathrm{H}$ by the regular rules of Luganda tonology). Second, the monosyllabic length of the second noun stem cannot be realized. We suggest that the absence of length on -twè and -bì is directly attributable to the fact that these compounds are single "tone words". According to the general rules of Luganda tonology (see Stevick [1969], Hyman [1982]), whenever a tone word has a final $\mathrm{H}$ tone and a toneless initial stem vowel, the $\mathrm{H}$ is realized on the second mora of the stem. In (80), the first stem of the compound is toneless, and the second stem provides the final $\mathrm{H}$ tone. Although the etymology of these compounds is transparent, in this case it is the phonology (tone) that requires them to be treated as one indivisible unit for the purpose of FVS. In other words, the option of accessing $\mathrm{N}_{3}$ is precluded.

\subsection{Reduplication}

In this section we shall examine the effects of FVS internally and externally to reduplicated forms. We shall begin by considering nouns and adjectives in §5.3.1, then verbs in \$5.3.2.

5.3.1. Nominal reduplication. By nominal we refer to both nouns and adjectives, which as seen in (81), can be reduplicated with a diminutive (and often pejorative) sense:

$\begin{array}{llll}\text { a. mùlímí } & \text { 'farmer' } & \text { mùlìmílìmí } & \text { 'sort of a farmer' } \\ \text { kìtábó } & \text { 'book' } & \text { kìtàbó.tàbó } & \text { 'not much of a book' } \\ \text { mùlámúzí } & \text { 'judge' } & \text { mùlàmúzì.làmùzí } & \text { 'mere judge' }\end{array}$

56 Toneless or non-tonic words generally realized with one $\mathrm{L}$ syllable followed by all $\mathrm{H}$ tone, as seen in these infinitives. 

b. kìzító
'heavy'
kìzìtózìtó
'rather heavy'
kìnénè
'big'
kìnéné.nénè
'somewhat big'
kìsányùfu
'happy'
kìsányúfú.sànyùfú ' rather happy'

The two parts of the reduplication are separated by a dot (.). It is observed that only the noun or adjective stem (and not the prefix) is involved in reduplication. 57 Since the diminutive or pejorative meaning is predictable, we shall not gloss reduplications to follow.

Turning to FVS, we consider first the realization of underlying final length in the reduplications in (82).
a. kíkòlwá
kìnyéèbwá
kìwábyò
b. kìkámbwé
kìbúgùmyé
kyààgálwà
'deed'
'groundnut'
'sickle'
'fierce'
'warm'
'beloved'
c. [ [ kíkólwá $]_{\mathrm{PW}}$ kòlwá $]_{\mathrm{PW}}$ etc.

kíkólwá.kòlwá

kìnyéébwá.nyéèbwá

kìwábyó.wábyò

kìkámbwè.kàmbwé

kìbúgúmyé.bùgùmyé

kyààgálwà.yàgàlwà 58

As seen, the first stem ends in a CGV sequence with a short vowel. We account for this by recognizing the dot in the above transcriptions as separating these forms into two parts. With the bracketing as indicated in (82c), PW-level FVS will apply at the end of each PW, creating the surface short vowels as needed.59

Consider now the examples in (83), whose unreduplicated forms have shown contour tone length within the CG:
a. mùsòtâ
'snake'
mùsòtá.sòtá
kìsìkî
'log'
kìsìkísìkí
mùvúbúkâ
'adolescent'
mùvúbúká.vùbùká

${ }^{57}$ There also are some tonal changes which are interesting but irrelevant to the issue of FVS. 58 The [y] of [yàgàlwa] is part of the stem.

${ }^{59}$ The bracketing in (82a), which is further justified by the tonology, involves a self-embedded PW, something which is outlawed by the strict layer hypothesis [Selkirk 1984; Nespor and Vogel 1986]. A separate paper is in preparation on the subject of PW's and will deal with this issue in some detail. 

b. kìgàzî
'wide'
kìgàzígàzí
kìgìmû
'fertile'
kìgìmú.gìmú
kìlàmû
'healthy'
kìlàmúlàmú

Again, PW-level FVS is responsible for the final short vowel on the first stem.

The reduplication of monosyllabic noun and adjective stems is somewhat different. As seen in (84),
a. kìdé
'bell'
kìdéé.dè.dé
màtá
'milk'
màtáá.tà.tá
mìtî
'tree'
mìtîitítî
b. kìsá
'empty'
kìsáá.sà.sá
kìtô
'young'
kìtóó.tó.tô
kìbî
'bad'
kìbîi.bí.bî

monosyllabic nominals must undergo a double reduplication in this construction. On the surface, only the first syllable of the reduplicated stem has a long vowel. To account for this, we propose that double reduplication is obtained in cyclic fashion, as shown in (85).
a. $k i-[$ [ [dee ] dee ] dee ]
b. $k i-[$ [ [ saa ] saa ] saa ]

On the first cycle, the M2 accent preserves the length on the first stem. When it is reduplicated, the long vowels of the second -dee and -saa successfully undergo FVS, since they are not protected by an M2 accent. The same holds for the third -dee and -saa.

We thus see that our analysis of FVS correctly predicts the surface lengths within nominal reduplications. As seen in (86), final length on reduplicated forms is identical to the facts we have observed in previous sections:
a. kíkólwá.kòlwà=kí
'which mere deed?'
kìkámbwè.kàmbwè=kí
'which rather fierce one?'
b. mùsòtá.sòtà=kí
'which excuse for a snake?'
kìgàzígàzì=kí
'which somewhat wide one?' 
c. kìdéé.dè.dè=kí

kìsáá.sà.sà=kí 'which miserable ol' bell?'

'which rather empty one?'

In (86a), underlying length is not preserved before the nominal enclitic $=k i$ 'which', nor is contour tone length preserved in (86b), since the reduplicated forms, unlike the corresponding simplex ones, do not have a final HL contour (cf. (83)). In (86c), monosyllabic length is preserved only on the first [CVV], showing that the cyclic analysis in (85) is correct. Finally, when reduplicated adjectives occur with the verbal enclitic $=m \hat{u}$, also a diminutizer, again only monosyllabic length is preserved:
a. kìkámbwé.kámbwé=mû
'rather fierce'
b. kìgàzígází=mû
'rather wide'
c. kìsáásá.sá=mû
'rather empty'

As we shall now see, similar facts are found in verbal reduplication.

5.3.2. Verbal reduplication. As seen in (88), verb stems may also be reduplicated, expressing actions which are done frequently or repeatedly. 60
a. kùlíimá
'to spy on'
kùlîimá.lìimá
kùsásúlá
'to pay'
kùsásúlá.sásúlá
kùbálágáná
'to count e.o.'
kùbálágáná.bálágáná
b. kùléètá
'to bring'
kùléètá.léétá
kùwúlìlá
'to hear'
kùwúlìlá. wúlilá
kùlábàgáná
'to see e.o.'
kùlábàgáná.lábágáná

As in the case of nominals, prefixes are never copied in verbal reduplication. 61 On the other hand, any suffixes on the stem are copied, as seen in the stems [bal-agan-a] 'count each other' in (88a) and [lab-agan-a] 'see each other' in (88b).

\footnotetext{
${ }^{60} \mathrm{As}$ in the case of nominal reduplication, there is sometimes a diminutivizing or pejorative connotation. Thus, Ashton et al [1954:426] gloss kùfúmbá.fúmbá, the reduplication of kưfúmbá 'to cook', as 'to play at cooking'.

61 Unlike nominal reduplication, reduplicated verb stems have exactly the same tonal pattern as their non-reduplicated counterparts, as seen in the two tonal patterns of infinitive stems realized either all $\mathrm{H}$ in (88a) or a single $\mathrm{H}+\mathrm{L}$ followed by the rest $\mathrm{H}$ in (88b).
} 
Returning to the issue of FVS, we see that underlying final length is not preserved on the first verb stem in reduplication:

(89)
a. kùliímwá
'to be spied on'
kùsásúlwá
'to be paid'
b. kùléètwá
kùwúlìlwá
'to be brought'
'to be heard'
c. àlíimyè
àsítàmyé
'he has spied on'
'he has squatted'
kùlîimwállímwá
kùsásúlwá.sásúlwá
kùléètwá.léétwá
kùwúlì lwá.wúlíwá
àliuimyè.lì̀myé
àsítàmyè.si tàmyé

The stems in (89a, b) all contain the passive suffix - $u-$, which in conjunction with the FV -a provides the underlying length, e.g. -liim-u-a 'be spied on'. The forms in (89c) involve the so-called modified base which, in these examples, ends in a /Cie/ sequence, providing underlying length. As seen, the first stem ends in a short Cwa or Cye syllable, indicating that PW-level FVS has applied to it.

As expected from the nominal pattern, monosyllabic length is preserved in verbal reduplication:

(90)
a. kùsá
kùmwá
kùgyá
b. kùtâ
kùnywâ
kùlyâ

'to grind'

'to shave'

'to fit in'

'to let go'

'to drink'

'to eat' kùsáá.sá

kùmwáá.mwá

kugyáá.gyá

kùtáà.tá

kùnywáà.nywá

kùlyáà.lyá

However, unlike the examples in (84), monosyllabic verb stems normally do not undergo double reduplication. 62

It is difficult, if not impossible, to determine whether contour tone length is preserved at the end of the first verb stem. One reason is that the reduplicated stem receives its tonal pattern as a whole. Consider, for example, the relative affirmative present tense forms in (91).

62 Occasionally speakers have offered us doubly reduplicated verb stems, but never as their first option. In any case, whether the infinitive is treated as nominal or verbal, a single reduplication is the rule, e.g. kùsáá.sàà=kwàngé 'my repeated grinding'. When occasionally provided, doubly reduplicated verb stems show the same length pattern as their nominal counterpart, e.g. kù-sáá.sá.sáá=kô. 
a. àliúmà

àsàsúlà

àgùlintilá

b. àléétâ

àwúlilâ

àlábílilâ 'he who spies on'

'he who pays'

'he who bribes'

'he who brings'

'he who hears'

'he who looks after' àlíimà.lì̀mà

àsàsúlà.sàsùlá

àgùlị̂i làgùlî lì lá

àléétá.léétâ

àwúlílá. wúlílâ

àlábílilálábílilâ

The examples in (91a), which have a toneless verb root, show a $\mathrm{H}$ tone on the second mora of the stem (underlined). As seen, this position is calculated from the beginning of the first stem in the reduplicated forms. In (91b), where the verb roots have underlying $H$ tone, this tense calls for a $H L$ fall on the FV. In the case of reduplicated stems, this means the FV of the second verb stem. We note also in the reduplicated forms in (91b) that there is no length on the FV of the first stem. We cannot draw any conclusions concerning the (non-)preservation of contour tone length, however, since there is no evidence that the first FV ever had a contour.

Since the FV HL verb tone pattern cannot provide evidence for or against preservation of contour tone length, consider the following verb stems in (92).
a. àbàlâ
'he who counts'
àbàláá.bàlá
b. àgùlâ
'he who buys'
àgùláá.gùlá
c. àlìmâ
'he who cultivates'
àlìmáálìmá

The verb roots -bal - 'count', -gul- 'buy', and -lim- 'cultivate' are underlyingly toneless. Hence, the stems in (92) receive a second mora $\mathrm{H}$ tone, exactly as in (91a). In (92), however, the second mora is also the FV, because these CVCV stems have only two moras. As seen, the first stem ends in a long vowel. However, it would be wrong to conclude that this unambiguously represents the preservation of contour tone length, because of the forms in (93).

a. kùbálá

kùgúlá

kùlímá 'to count'

'to buy'

'to cultivate' kùbáláá.bálá

kùgúláá.gúlá

kùlimáá.limá 

b. kùlábà
'to see'
kùlábàà.lábá
kùtémà
'to chop'
kùtémàà.tèmá
kùsímà
'to dig'
kùsímàà.sìmá

Verb reduplication has the curious idiosyncrasy of requiring that the FV on the verb stem be long if the stem consists of only two moras. 63 Thus, the final length observed on the first stem of the reduplications in (92) may be due to this requirement, not to contour tone length. 64 As soon as another mora is added to any of the above stems, the FV of the first verb stem is short, as seen in (94).
a. kùbálilá
'to count for'
kùbálilá.bálilá
kùlimísá
'to cultivate with'
kùlimísálimisá
b. kùlábìlá
'to see for'
kùlábìlálábílá
kùsímìsá
'to dig with'
kùsímìsá.símísá

The examples in (94) show the addition of an applied -il- or causative/instrumental -is- suffix. (cf. also the reciprocal -agan- suffix illustrated in (88)). Finally, consider the examples in (95).
(95)
a. kùbálwá
'to be counted'
kùbálwáá.bálwá
kùgúlwá
'to be bought'
kùgúlwáá.gúlwá
kùlábwà
'to be seen'
kùlábwà.lábwá

${ }^{63}$ This idiosyncrasy provides a good test for mora counting within verb stems. First, as can be seen in the following reduplications,
(i) kùgéndá
'to go'
'to cook'
kùgéndá.géndá
kùfúmbá
'to mould'
'to choose'
kùfúmbá.fúmbá
(ii) kùbûmbá
kùlôndá
kùbûmbá.búmbá
kùlôndá.lóndá

the nasal of -CVNC- roots, which is a tone-bearing unit in Luganda, counts as a mora for this purpose as well. As a result, the final vowel of the first verb stem is short in these reduplications. On the other hand, the examples such as the following demonstrate that the initial vowel of -VCroots is monomoraic:
(iii) kwè̀lá

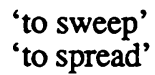
kwèèlá.yélá
|-el-1
kwààlá
'to bask'
kwààláa.yálá
$|-a l-|$
(iv) kwóòtá
'to increase'
kwóótàà.yótá
$|-\sigma t|$
kwáálàà.yálá
|-ál-|

The length of the FV of the first verb stem is thus long (and the length of the [kwVV] syllables due to gliding of the infinitive $/ u /$ + compensatory lengthening).

64 Actually, the rules we are assuming would not have produced contour tone length on the first FV in any case, since it is not final within the whole (reduplicated) verb stem. 

b. àlìmyê
'he has cultivated'
àlìmyéélìmyé
àlábyè
'he has seen'
àlábyèè.làbyé
àtémyè
'he has chopped'
àtémyèè.tèmyé

Length on the final CGV is preserved on the passive stems in (95a) and on the modified base stems in (95b). However, this is due not to the underlying length of these final syllables, but rather to the fact that these are (after PW-level FVS) bimoraic verb stems. We must assume that the underlying length of such forms is removed, but replaced just in case the stem is bimoraic.

With the addition of the bimoraic lengthening rule, our analysis covers the facts of FVS in verbal reduplications. However, in order not to preserve underlying length on the first verb stem, we have to ensure that its FV is not invisible to PW-level FVS (as it is in the case of simplex verb stems). We suggest that the reduplicated stem is created before the marking of invisibility. Thus, only the FV of the entire stem will be invisible.65 By marking this FV invisible, we make the prediction that it will have the same length realizations as the FV of simplex verb stems. We now briefly show that this is correct.

In (96) we see that underlying length is preserved before a verbal enclitic:

(96)
a. kùlîimwállîimwáá=kô
kùléètwá.léétwáá=kô
kùfúmbwá.fúmbwáá=kô
b. àlîimyé.líimyéé=kô
àsítámyé.sítámyéé= $k \hat{o}$
àfúmbyé.fúmbyéé=kô
'to be spied on a little'
'to be brought a bit'
'to be somewhat cooked'
'he has spied a little'
'he has squatted a bit'
'he has cooked a little'

As before, we have illustrated both [Cwaa] passive endings and [Cyee] modified based endings. In order for the length to be protected from PW-level FVS, the FV of the entire reduplicated verb stem must be invisible, as discussed in $\$ 4.1$.

Since underlying length is present in all monosyllabic verb stems, it is not surprising to observe in (97) that monosyllabic stems are likewise long before the enclitic $=k \hat{o}$ :

65If the FV of the stem is marked invisible before reduplication, we would first have to ensure that the FV, although invisible, is in fact copied. If it is copied, its invisibility would then automatically be removed from the first stem by the peripherality condition. 
a. kùsáá.sáá=kô

kùmwáá.mwáá=kô

kùgyáá.gyáá=kô

b. kùtáà.táá=kô

kùnywáà.nywáá=kô

kùlyáà.lyáá=kô 'to grind a little'

'to shave a bit'

'to fit in somewhat'

'to let go a little'

'to drink a bit'

'to eat a bit'

Finally, (98) presents the realization of contour tone length.

(98)
a. mùlèètè.lèètéè $=k \hat{o}$
mùwùlìlè. wùlì léè $=k \hat{o}$
mùlàbìlì lè.làbìlì léé $k \hat{o}$
b. àléétá.léétá=kô
àwúlilá. wúlílá=kô
àlábiliılálábiliılá= $k \hat{o}$
'(you pl.) bring a little!'
'(you pl.) hear a bit!'
'(you pl.) look after a bit!'
'he who brings a little'
'he who hears a bit'
'he who looks after a bit'

In (98a) the plural imperative form requires a final HL contour tone which is preserved, along with its length, before the enclitic $=k \hat{o}$. The verb forms in (98b) were seen with a final HL falling tone in (91b). When they are followed by an enclitic, neither the fall nor the length surfaces, as we expect from the verbal pattern.

To summarize this subsection, our analysis accounts for all of the length realizations both on the first and the second stem of reduplicated nouns and verbs. 66

${ }^{66}$ All other reduplications (e.g. of numerals) in Luganda involve repetition of full words:
$\begin{array}{ll}\text { (i) bìbílì } & \text { 'two' } \\ \text { bìsátù } & \text { 'three' } \\ \text { bìtáànó } & \text { 'five' }\end{array}$
bìbílí bíbílì
bìsátú - bísátù
bì táánó - bítáànó
'two by two'
'three by three'
'five by five'
(ii) kìmû
bìnâ
'one'
'four'
kìmú - kímû
bìná - bínâ
'one by one'
'four by four'

As such the above reduplicated numerals (given with $\mathrm{ki}$-/bi- noun class $7 / 8$ prefixes) are similar to compounds. Notice that neither monosyllabic nor contour tone length is realized on the first occurrence of the numerals in (ii). 


\section{Conclusion}

In the preceding sections we have provided a rather detailed account of FVS, which has been discovered to be considerably more complex than previous literature suggests. In particular, we have found it necessary to establish two applications of FVS: one at the end of a PW, one at the end of a CG. In addition, we have had to invoke the device of invisibility to account for the differential effect of PW-level FVS on nouns vs. verbs. By restricting invisibility of the FV to verbs, we are able to capture the intuition that nouns undergo word-edge phonology earlier than verbs. The analysis also recognizes a stem second mora accent to protect monosyllabic length at the PW level and makes crucial use of rule ordering to predict the surface realization of contour tone length. The result is that PW-level FVS will apply differently according to grammatical category and according to the source of the final length, while CG-level FVS will apply across the board to all final long vowels. 67

In this brief conclusion, we shall consider apparent counterexamples: first, cases of apparent underapplication of FVS, where a long vowel surfaces that should have been short; second, cases of apparent overapplication of FVS, where a short vowel surfaces that should have been long. After investigating these putative counterexamples we shall in fact conclude that there is relatively little residue left by the analysis.

6.1. Underapplication of FVS. As stated above, all vowels are short at the end of a CG. Of course, if there is a juxtaposition of vowels across a CG, length will always surface, as in (99).
a. òmùlìmì + òmû
$\rightarrow \quad$ [òmùlìmyòòmû]
'one farmer'
farmer one
b. yàlábà + òmùlímî
[yàlábòòmúlímî]
'he saw a farmer'

In (99a) the FV [i] of òmúlimí 'farmer' glides and the vowel [o] of [òmû ] 'one' becomes long by compensatory lengthening. In (99b) the FV [a] of yàlábà 'he saw' elides with compensatory lengthening of the $[o]$ of the following word 'farmer'. Although there is a long [oo] in each phrase, it can be seen from the inputs that each consists of two CG's, the first of which ends in a short vowel. In other words, FVS has no effect because the length is derived at the phrase level. Because many Luganda words begin with a vowel and all Luganda words end in a

67In a paper we have planned on the PW in Luganda, we question whether the CG is needed in Luganda at all. At the very least one has to accommodate two different applications of FVS which in this paper we identify as PW-level vs. CG-level FVS. 
vowel, phrasal length will be pervasive in surface forms. It does not, however, constitute an exception to FVS.

Also not a counterexample is any final length that results from intonation. In (100) we illustrate intonational lengthening that marks an intensification on adjectives:
(100) a. kìzító
'heavy'
kìzítóóò
'very heavy'
b. kìgàzî
'wide'
kìgàziîi
'very wide'
c. kìnénè
'big'
kìnénééè
'very big'

Since this length is an intonational feature, we have a number of ways to prevent it from undergoing CG-level FVS, e.g. the length can be placed outside the CG, the length can be assigned after CG-level FVS has applied, etc.

We can assume that length appearing finally on ideophones also has an intonational source. This is seen clearly in the examples from Ashton et al [1954:427] in (101), where the ideophones show the same tone pattern and intensification as just seen on adjectives: 68
(101) a. è̀mmûndù né évùgá bè ddúúù
'the gun went off bang'
b. ǹnássà èkíkkòwé bè wúúù
'I sighed relief whew'
c. èkìtélèkè nè kígwá bè ggwááà
'the parcel fell kerplunk'

We note in all of these examples that the final intonational length on adjectives or ideophones also violates the otherwise general syllable structure canons of the language. The above transcriptions are intended to indicate that there are more than two vowel lengths, i.e. more than the two moras that are permissible within a single syllable. The exact number of syllables and moras is not immediately obvious and probably can vary according to the degree of intensification.

6.2. Overapplication of FVS. With the above account of "exceptional" final length, we now consider cases where shortening appears to have applied internally to a PW, as in the examples in (102).

(102) a. kwété

b. Iwàkkìpúmpúlú

ǹnábyèjéégùùlá 'beer made from maize'

'cattle trypanosomiasis'

'spendthrift'

68Ideophones are frequently introduced by the particle (proclitic?) bè. 
We know of only the one monomorphemic word in (102a) that has a short CGV sequence within it. We assume that it must simply be entered this way in the lexicon. The forms in (102b) are polymorphemic and each have an unexplained short CGV. The initial syllable [Iwa] in lwàkìpúmpúlú appears to be a combination of class $11 \mathrm{lu}$ - plus the GL -aa. If so, it should have a long vowel (cf. §1.1) and the noun as a whole should be class 11, not class 1a. Instead, it again appears necessary to place this short CGV in the lexical entry. ${ }^{69}$ Similarly, the short vowel in the syllable [bye] in (102c) cannot be explained. While it would be expected to be short if it were the object cleft or relative marker (cf. $\S 1.1$ ), the part that follows (jéégùùlá ) cannot be identified even as a stem, let alone a word. 70

It thus seems necessary to enter a few exceptional short CGV sequences in the lexicon. Not to be included among these, however, are the following frequently cited "exceptions":
(103) a. òkúggyá=kô 'except'
(cf. kùggyá 'to take off, remove')
b. kú-ggyà=kô 'to get burnt a bit'
c. g̀gwisô
'large needle'
(cf. mpîddé/ǹjî̀ddé 'I have gotten burnt')
(cf. m̀̀ísô 'needle')

These all involve $[g g y]$ or $[g g w]$ sequences followed by a short vowel. In this case we do not have a CVV sequence, but rather a geminate glide: expected - $y y$ surfaces as [ggy] and expected -ww- surfaces as [ggw]. As seen in the comparisons in $(103 \mathrm{~b}, \mathrm{c})$, these glides are sometimes derived from historical ${ }^{*} p$. In any case, we need not view forms such as in (103) as cases where FVS has overapplied.

Another case of apparent overapplication can be seen in (104).
(104) a. myámyámyá
'very (shiny)'
b. myúmyúmyú
'very (red)'
c. nywánywánywá
'very (cold)'

These ideophones consist of a double reduplication of a CGV syllable possessing a short vowel. We can account for these short vowels if we recognize each occurrence of the CGV syllable as a separate PW. Since ideophones are not verbs, their FV will not be invisible, and hence PW-level FVS will correctly apply to each syllable.

\footnotetext{
${ }^{69}$ The following part kìpúmpúlú does not exist by itself, but there is another entry kìpúmpúlì 'cattle plague' [Snoxall 1967:138] which is clearly related and where the initial ki- is the class 7 prefix.

70The formative ǹna frequently occurs before class la nouns, which this is.
} 
With all of the above accounted for, we have left the most difficult and intriguing case for last. In (105) we give different realizations of verb stems containing both a causative $[y]$ and a reciprocal suffix -agan-:

(105) a. kùlimyá

kùlimyágáná

kùlímágányá

?kùlimyágányá

b. kùlábyà

kùlábyàgáná

kùlábágànyá

?kùlábyàgányá 'to cause to cultivate'

'to cause each other to cultivate'

c. [ [ kùlímyá $]_{\mathrm{PW}}$ gáná $]_{\mathrm{PW}}$

[ [ kùlábyà $]_{\mathrm{PW}}$ gáná $]_{\mathrm{PW}}$

'to cause to see'

'to cause each other to see'

As can be seen, there is some variation in the linear ordering of the two suffixes in Luganda. Speakers even occasionally accept the causative [y] before and after reciprocal -agan - in the same form. What is critical for us is that when it occurs before -agan-, the following vowel [a] is short, i.e. *kùlimyáágáná, etc. The question that confronts us is whether this is a case of word-internal FVS? In other words, do such verb stems consist of two PW's, as in (105c)? While this would help us obtain the short vowel we require, it raises questions about the internal structure of verb stems that extend beyond the scope of the present paper. ${ }^{71}$ For this reason, we leave this issue open as a subject for further research. 72

${ }^{71}$ E.g. verb extensions are always vowel-initial. Hence the reciprocal extension should be -agan-, not -gan-.

${ }^{72} \mathrm{We}$ cannot refrain from noting, however, that research completed after the writing of this paper suggests, first, that the causative suffix $-i$ - and the passive suffix $-u$ - are moraic (adding syllable weight) only when they are directly followed by the final vowel morpheme. Thus, when $-i-$ precedes -agan- it is non-moraic. See Hyman \& Katamba [1992] for discussion. 


\section{REFERENCES}

Ashton, E.O., E.M.K. Mulira, E.G.M. Ndaluwa \& A.N. Tucker. 1954. A Luganda Grammar. London: Longmans, Green \& Co.

Clements, George N. 1986. "Compensatory lengthening and consonant gemination in LuGanda." In Leo Wetzels and Engin Sezer (eds.), Studies in Compensatory Lengthening, pp. 37-77. Dordrecht: Foris.

Cole, Desmond T. 1967. Some Features of Ganda Linguistic Structure. Johannesburg: Witwatersrand University Press.

Halle, Morris \& Jean-Roger Vergnaud. 1980. "Three dimensional phonology." Journal of Linguistic Research 1:83-105.

Hayes, Bruce. 1982. "Extrametricality and English stress." Linguistic Inquiry 13:227-276.

Herbert, Robert K. 1975. "Reanalyzing prenasalized consonants." Studies in African Linguistics 6:105-124.

Herbert, Robert K. 1976. "A reanalysis of Luganda vowels." Afrika und Übersee 59:113-124.

Hyman, Larry M. 1982. "Globality and the accentual analysis of Luganda tone." Journal of Linguistic Research 1:1-40.

Hyman, Larry M. 1988. "Direct vs. indirect syntactic conditioning of phonological rules." Proceedings of ESCOL 1987, pp. 147-163. Ohio State University.

Hyman, Larry M. 1989. “Accent in Bantu: an appraisal." Paper presented at 20th Annual Conference on African Linguistics, April 20, 1989, University of Illinois, Urbana. Studies in the Linguistic Sciences.19:115-134.

Hyman, Larry M. \& Francis Katamba. 1990. "The augment in Luganda tonology." Journal of African Languages and Linguistics 12:1-45.

Hyman, Larry M. \& Francis Katamba. 1992. "A new approach to tone in Luganda." Unpublished ms., University of California at Berkeley and University of Lancaster. 
Hyman, Larry M., Francis Katamba \& Livingstone Walusimbi. 1987. "Luganda and the strict layer hypothesis." Phonology Yearbook 4:87-108.

Inkelas, Sharon. 1989. "Prosodic constituency in the lexicon." Unpublished $\mathrm{PhD}$ dissertation, Stanford University.

Katamba, Francis. 1974. "Aspects of the grammar of Luganda." Unpublished $\mathrm{PhD}$ dissertation, University of Edinburgh.

Klavans, Judith L. 1985. "The independence of syntax and phonology in cliticization." Language 61:95-120.

Meeussen, A.E. 1967. "Bantu grammatical reconstructions." Annales du Musée Royal de l'Afrique Centrale, Série 8, Sciences Humaines, No. 61, pp. 81-121. Teruven.

Nespor, Marina \& Irene Vogel. 1986. Prosodic Phonology. Dordrecht: Foris.

Poser, William. 1984. "The phonetics and phonology of tone and intonation in Japanese." Unpublished PhD dissertation, MIT.

Selkirk, Elisabeth O. 1984. Phonology and Syntax: the Relation between Sound and Sructure. Cambridge, MA: MIT Press.

Snoxall, R.A. 1967. Luganda-English Dictionary. Oxford: Oxford University Press.

Stevick, E.W. 1969. "Pitch and duration in Ganda." Journal of African Languages 8:1-28.

Tucker, A.N. 1962. "The syllable in Luganda: a prosodic account." Journal of African Languages 1:122-166.

Walusimbi, Livingstone. 1976. "Relative clauses in Luganda." Unpublished $\mathrm{PhD}$ dissertation, UCLA. 
